(C) The Authors 2018. This is an Open Access article, distributed under the terms of the Creative Commons

Attribution licence (http://creativecommons.org/licenses/by/4.0/), which permits unrestricted re-use,

distribution, and reproduction in any medium, provided the original work is properly cited.

\title{
A critical review of the role of milk and other dairy products in the development of obesity in children and adolescents
}

\author{
Anestis Dougkas ${ }^{1 *}$, Suzanne Barr ${ }^{2}$, Sheela Reddy ${ }^{3}$ and Carolyn D. Summerbell ${ }^{4}$ \\ ${ }^{1}$ Institut Paul Bocuse Research Centre, Institut Paul Bocuse, Château du Vivier, BP 25, 69131 Ecully Cedex, France \\ ${ }^{2}$ Department of Medicine, Imperial College London, London, UK \\ ${ }^{3}$ Department of Health, London, UK \\ ${ }^{4}$ Department of Sport and Exercise Sciences, Durbam University, Durham, UK
}

\section{Abstract}

Existing reviews suggest that milk and other dairy products do not play a role in the development of obesity in childhood, but they do make an important contribution to children's nutrient intake. It is thus curious that public health advice on the consumption of dairy products for children is often perceived as unclear. The present review aimed to provide an overview of the totality of the evidence on the association between milk and other dairy products, and obesity and indicators of adiposity, in children. Our search identified forty-three cross-sectional studies, thirty-one longitudinal cohort studies and twenty randomised controlled trials. We found that milk and other dairy products are consistently found to be not associated, or inversely associated, with obesity and indicators of adiposity in children. Adjustment for energy intake tended to change inverse associations to neutral. Also, we found little evidence to suggest that the relationship varied by type of milk or dairy product, or age of the children, although there was a dearth of evidence for young children. Only nine of the ninety-four studies found a positive association between milk and other dairy products and body fatness. There may be some plausible mechanisms underlying the effect of milk and other dairy products on adiposity that influence energy and fat balance, possibly through fat absorption, appetite or metabolic activity of gut microbiota. In conclusion, there is little evidence to support a concern to limit the consumption of milk and other dairy products for children on the grounds that they may promote obesity.

\section{Key words: Dairy products: Milk: Adiposity: Obesity: Children: Adolescents}

\section{Introduction}

\section{The burden of childhood obesity}

Childhood overweight and obesity represent significant shortand long-term challenges for individuals and healthcare, both in Europe and worldwide ${ }^{(1)}$. Globally, 41 million children under the age of 5 years were overweight or obese in 2014; $39 \%$ of adults aged 18 years and over were overweight in 2014, and $13 \%$ were obese ${ }^{(2)}$. Importantly, the prevalence of obesity is even higher among those children from poor socio-economic backgrounds in most middle- and high-income countries ${ }^{(3)}$.

The burgeoning levels of childhood overweight and obesity are a public health concern because childhood obesity is linked to a range of physical and psychological illnesses during childhood $^{(4)}$, and tracks through to adulthood ${ }^{(5)}$.

Rates of obesity and overweight are increasing globally ${ }^{(6)}$. Interventions and public health messages that promote a healthy weight tend to give simple messages to the public ${ }^{(7,8)}$. These include reducing the consumption of sugar-sweetened beverages and energy-dense snacks, promoting the consumption of fruits and vegetables ${ }^{(7)}$, whilst promoting water as a beverage of choice. However, advice on milk and other dairy products is usually unclear and limited, and tends to be perceived as confusing by the public ${ }^{(9)}$. Dairy foods play an important role in the diets of children and adolescents but are often under scrutiny because of their energy and fat content ${ }^{(10,11)}$. For example the UK's Nutrient Profile Modelling suggests some cheeses and yoghurts are 'unhealthy' because there is a focus on fat and saturated fat content with little consideration for micronutrients ${ }^{(12)}$

\section{Classification of obesity in children}

BMI, calculated as weight in kg divided by height in metres squared $\left(\mathrm{kg} / \mathrm{m}^{2}\right)$, has been shown to correlate strongly with adiposity (excess body fat) in adults and children, and in turn with health ${ }^{(13)}$. We categorise a child's level of fatness by comparing (plotting) their BMI against age- and sex-specific thresholds (based on centiles) derived from a reference population. In the context of the present review, most studies used BMI as their measure of body fatness, which included BMI, BMI standard deviation score and BMI $z$ score. The remaining studies used the outcome measures of percentage body fat, waist circumference and body weight status. We have used 'obesity and indicators of adiposity' as a collective term to describe these varying outcome measures.

\footnotetext{
Abbreviation: IGF-1, insulin-like growth factor-1.

* Corresponding author: Anestis Dougkas, email anestis.dougkas@institutpaulbocuse.com
} 


\section{Definition of milk and other dairy products}

Under European Union regulations, 'milk' refers exclusively to the mammary secretion of animals obtained from milking ${ }^{(14)}$. The terms milk, whey, cream, butter, buttermilk, cheese and yoghurt are protected and reserved exclusively for dairy products. In the present review, the dairy food group contains milk, cheese and yoghurt, and is described as a group of foods containing $\mathrm{Ca}$, which are to be consumed as a source of $\mathrm{Ca}^{(15)}$. Butter is not included in the dairy food group as it contains no $\mathrm{Ca}$ and is considered to be a fat, and is therefore excluded from the present review. Plant-based milk-like products do not have the same nutrient composition as milk or other dairy products and therefore are not included in this review ${ }^{(16)}$. Throughout this publication the terms 'milk' and 'other dairy products' refer to liquid drinking milk and foods containing $\mathrm{Ca}$ which are made from milk such as cheese, yoghurt and fromage frais, ice-cream and dairy desserts (further examples are listed in online Supplementary Table S1) ${ }^{(17)}$.

\section{Contribution of milk and other dairy products to dietary intake}

The nutritional value and quality of milk and other dairy products vary across the globe and depend on a number of factors including animal breed, genetic variation within breeds, health and diet of the animal, geographical location of grazing and animal husbandry ${ }^{(18)}$. Generally, dairy products are nutrient rich and a source of protein, $\mathrm{Ca}$, riboflavin, iodine, $\mathrm{P}$ and vitamin $\mathrm{B}_{12}{ }^{(17)}$; however, their nutrient content varies by type of dairy product (for example, cheese and yoghurt have a different nutrient composition as outlined in online Supplementary Table S2) ${ }^{(17)}$

As defined by European Union regulations, milk is high in protein (defined as having at least $20 \%$ of the energy value of the food provided by protein; $3.6 \mathrm{~g}$ per $100 \mathrm{ml}$ ), Ca (124 mg per $100 \mathrm{ml})$, vitamin $\mathrm{B}_{12}(0.9 \mu \mathrm{g}$ per $100 \mathrm{ml})$, riboflavin $(0.24 \mathrm{mg}$ per $100 \mathrm{ml}$ ) and iodine $(31 \mu \mathrm{g}$ per $100 \mathrm{ml})$ and is a source of $\mathrm{K}$ (160 mg per $100 \mathrm{ml}), \mathrm{P}(97 \mathrm{mg}$ per $100 \mathrm{ml})$ and vitamin $\mathrm{B}_{5}(0.7 \mathrm{mg}$ per $100 \mathrm{ml})^{(17)}$. Whole milk is $3.7 \%$ fat, while skimmed milks are low in fat $(0.3 \% \text { to } 1.8 \%)^{(17)}$. Plain milk is low in $\mathrm{Na}$ and contains no added sugars ${ }^{(17)}$. Cheese is high in protein and full-fat varieties of hard cheeses (but not reduced fat) are a source of vitamin A (387.5 $\mu \mathrm{g}$ per $100 \mathrm{~g}$ ) and $\mathrm{Zn}(4.1 \mathrm{mg} \text { per } 100 \mathrm{~g})^{(17)}$ but are considered high in fat. Auestad et al. ${ }^{(19)}$ suggest that dairy product intakes make significant contributions to both underconsumed nutrients and overconsumed nutrients ${ }^{(19)}$. In developed countries dairy products contribute to over $45 \%$ of children's Ca intakes, as well as 34\% of their iodine intakes, $20 \%$ of their $\mathrm{K}$ intake, $20-40 \%$ of their vitamin $\mathrm{B}_{12}$ and $20 \%$ of their vitamin $\mathrm{A}$ intake. In terms of overconsumed nutrients, dairy products contribute to just over $10 \%$ of their energy intakes, $10 \%$ of their $\mathrm{Na}$ intake and $20-24 \%$ of their saturated fat intake ${ }^{(19)}$.

\section{Consumption trends in milk and other dairy products}

Milk consumption varies around the world, from 10 to $212 \cdot 2 \mathrm{~kg}$ per capita per year ${ }^{(20)}$. Industrialised countries consume the most milk at $212.2 \mathrm{~kg} /$ year and East Asian countries consume the least at $10 \mathrm{~kg} /$ year $^{(20)}$. Data from the Global Nutrition and Policy Consortium show that younger children consume more milk than older children $(338 \cdot 1 \text { and } 147 \cdot 2 \mathrm{~g} / \mathrm{d} \text {, respectively })^{(21)}$.

\section{Existing review-level evidence from observational and intervention studies of the impact of milk and other dairy products on childhood and adolescent obesity and indicators of adiposity}

The association between dairy products and body composition has been widely reviewed with data from both observational and intervention studies, of different study designs, in children and in adolescents. Examples of reviews and meta-analyses include Louie et $a l .{ }^{(22)}$, Dror \& Allen ${ }^{(23)}$, Dror ${ }^{(24)}$, Lu et $a l^{(25)}$, Wang et $a l .{ }^{(26)}$ and Kouvelioti et $a l .{ }^{(27)}$. Examining the evidence by study design, a recent meta-analysis of mainly (but not exclusively) seven cross-sectional studies by Wang et al. ${ }^{(26)}$ found that intake of total dairy products was associated with a decreased risk of obesity in children (pooled OR 0.54; $95 \%$ CI $0 \cdot 38,0.77$ ). However, this pooled meta-analysis included mainly cross-sectional studies, which are susceptible to reverse causality and conducted in Asian populations with high heterogeneity between the studies. A recent meta-analysis of ten prospective cohort studies found that children in the highest dairy product intake group at baseline were $38 \%$ less likely to be overweight or obese over time relative to those who were in the lowest group ${ }^{(25)}$. An increase of one serving/d of dairy products was linked with a $0.65 \%$ lower body fat and a $13 \%$ lower risk of overweight/obesity. However, another recent systematic review of randomised intervention trials ${ }^{(27)}$ showed that eleven out of the fourteen studies demonstrated a neutral effect of milk consumption on body composition in children and adolescents, highlighting the difference in the results based on the type of study.

The most comprehensive review to date is a meta-analysis of combined results from twenty-two studies selected by the authors, which included cross-sectional, prospective cohort and intervention studies ${ }^{(24)}$. This review found no association between dairy product consumption and adiposity in preschoolers and school-aged children, although there was an inverse association between dairy product intake and adiposity in adolescents (average effect size -0.26 (95\% CI -0.38, -0.14); $P<0.0001)$. However, this meta-analysis had a few deficiencies and there was strong evidence of high study heterogeneity as seen in the $I^{2}$ statistics $\left(I^{2}=0 \cdot 72\right)$. The difficulty in comparing or combining results from different studies is due to the high heterogeneity in terms of exposures (type of dairy products or serving portion) and outcomes (BMI, weight change or adiposity).

The existing evidence, as summarised in the above reviews and meta-analyses, shows consistently that milk or dairy product consumption in children either has no relationship with weight status, or has an inverse relationship with excess weight gain (also reported in various ways). However, there were only a limited number of studies included in the meta-analyses due to the diversity and high heterogeneity between studies, which 
are often susceptible to risk of bias and inconsistency and also publication bias ${ }^{(28)}$. Therefore, we argue that a critical and upto-date evaluation of the available scientific evidence on this topic is lacking. First, the existing reviews are not comprehensive in their inclusion of available evidence from different study designs. Examination of individual studies contributing to narrative summaries will enable us to have more complete reflection and wide overview of studies dealing with dairy products and obesity and indicators of adiposity. Second, it remains unclear whether the associations reported relate equally to all dairy products, milk and other dairy products, as none of the systematic reviews or meta-analyses reported differences between different types of milk and/or other dairy products, and obesity and indicators of adiposity, in children and adolescents. Third, it is unclear whether the associations reported changed during childhood.

\section{Scope of the review}

The present review aims to provide an overview of the totality of the available evidence taken from cross-sectional studies, prospective longitudinal studies and intervention studies that have reported on the associations between intakes of milk and other dairy products, and obesity and indicators of adiposity, in children. This critical review also aims to explore whether any associations identified related equally to all milk and other dairy products. It also provides context for these findings, specifically in terms of the mechanisms by which milk and other dairy products might make an impact on obesity and indicators of adiposity in children and adolescents.

\section{Research methodology}

The literature for English-language articles published from January 1990 up to June 2017 was reviewed by searching the following three databases: ISI Web of Knowledge/Web of Science (Thomson Reuters, UK), PubMed (US National Library of Medicine National Institutes of Health) and Google Scholar (Google, UK). Search terms included 'dairy', 'milk', 'cheese', 'yoghurt', 'calcium', 'obesity', 'adiposity', 'overweight', 'body fatness', 'body weight', 'children', 'adolescent', 'girls', 'boys' and combinations of these. In addition, reference lists of identified published articles as well as of previous narrative, systematic reviews and meta-analyses were searched for citations of relevant publications. A total of 981 hits were retrieved. All observational and intervention studies conducted in adults, in nonhealthy children and those which assessed body weight in infants $(<1$ year) were not included in this review. Studies that examined exclusively $\mathrm{Ca}$ supplements in relation to childhood or adolescent obesity were also excluded. However, studies that compared directly the effect of dairy products or dietary Ca with Ca supplements on adiposity were included, as they provide a better understanding of the putative functional properties of bioactive constituents in milk and other dairy products. Studies that examined exclusively butter were not included, as according to the United States Department of Agriculture, any milk products with little to no $\mathrm{Ca}$ are not included in the dairy food group ${ }^{(15)}$. Studies that had bone density as the primary outcome but included body weight or measures of body composition were included in the present review. Using these selection criteria, a total number of forty-three cross-sectional studies, thirty-one longitudinal cohort studies and twenty intervention (randomised controlled trial) studies were identified that examined the association/impact of dairy milk and other dairy products on childhood and adolescent obesity and indicators of adiposity. Fig. 1 summarises the literature search strategy.

Using the same three databases and predefined publication dates, the search terms 'dairy', 'milk', 'calcium', 'mechanisms', appetite', 'fat oxidation', 'fat metabolism', 'gut microbiota', 'energy intake', 'satiety', 'children', 'adolescent', 'girls', 'boys' and combinations of these were used for the studies mentioned in the mechanistic section of the present review. Mechanistic studies in cells or animals were limited to searches of the reference lists of identified published studies and relevant reviews for citation of relevant publications.

We have summarised the evidence base, which we identified by study design; cross-sectional studies, longitudinal studies, and intervention studies and provided a narrative summary for the studies we identified by study design. As this is not a systematic review, we did not conduct a meta-analysis by study design but summarised the findings for each study in Tables 1 and 2 and online Supplementary Table S3. Symbols $\uparrow$ and $\downarrow$ indicate a statistically significant positive and negative effect/ relationship, respectively, between dairy milk and other dairy products and obesity and indicators of adiposity, with $\leftrightarrow$ indicating no statistically significant effect/relationship or a neutral effect. Such a simple tabulated summary allowed us to draw overall conclusions for this narrative review, although we did not undertake a detailed assessment of quality of individual studies. We have learnt from other reviews we have published that this type of simple tabulated summary can be helpful for

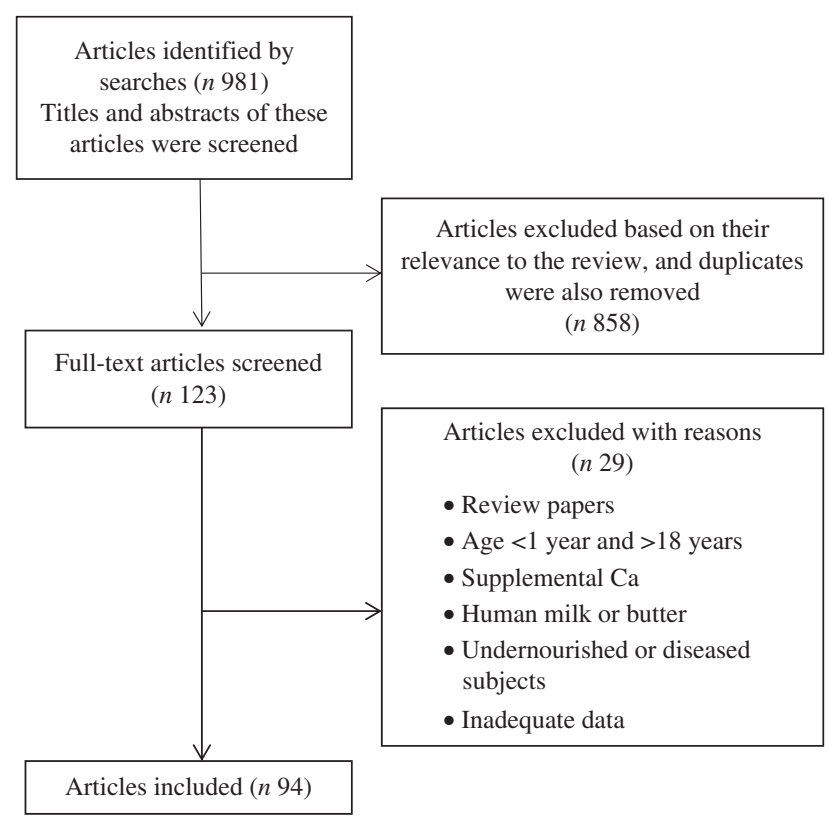

Fig. 1. Flow diagram for the selection of eligible studies. 
Table 1. Prospective studies $(n$ 31) that measured milk and other dairy product consumption at baseline and change in body composition over time in children

\begin{tabular}{|c|c|c|c|c|c|}
\hline Reference & Details & Exposure & Results and conclusion & Adjustment & Effect \\
\hline $\begin{array}{l}\text { Carruth \& } \\
\text { Skinner } \\
(2001)^{(45)}\end{array}$ & $\begin{array}{l}n 53 \text { ( } 29 \text { boys) } \\
\text { Age: } 2-2 \cdot 3 \text { years, about } 6 \text { years } \\
\text { follow-up } \\
\text { USA }\end{array}$ & $\begin{array}{l}\text { Dietary Ca and } \\
\text { total dairy } \\
\text { products }\end{array}$ & $\begin{array}{l}\text { Average dairy product consumption over the years } \\
\text { was associated with lower \%BF ( } \beta-3.54 \text { (SE 1.04); } \\
\begin{array}{l}P=0.001) \text { and BF g }(\beta-907.06 \text { (SE 284.06); } \\
P=0.003)\end{array}\end{array}$ & Sex, BMI, Ca, protein, carbohydrates and fat & $\downarrow$ \\
\hline $\begin{array}{l}\text { Skinner et al. } \\
\qquad(2003)^{(46)}\end{array}$ & $\begin{array}{l}n 52(25 \text { boys }) \\
\text { Age: } 2-2 \cdot 3 \text { years, } 8 \text {-year } \\
\text { follow-up } \\
\text { USA }\end{array}$ & Dietary Ca & $\begin{array}{l}\text { Average dietary } \mathrm{Ca} \text { intake over the years was } \\
\text { associated with lower \%BF in various models } \\
(P=0.02 \text { to } 0.04)\end{array}$ & Sex, total fat, sedentary activity & $\downarrow$ \\
\hline $\begin{array}{l}\text { Phillips et al. } \\
\qquad(2003)^{(33)}\end{array}$ & $\begin{array}{l}n 196 \text { (girls) } \\
\text { Age: } 8-12 \text { years, } 4 \text { years } \\
\text { post-menarche } \\
\text { USA }\end{array}$ & $\begin{array}{l}\text { Dairy } \mathrm{Ca} \text { and total } \\
\text { dairy products }\end{array}$ & $\begin{array}{l}\text { Dairy product consumption and Ca consumption } \\
\text { were not associated with BMI } z \text { score or } \% \mathrm{BF} \\
\text { during adolescence }(P>0.05)\end{array}$ & $\begin{array}{l}\text { Physical activity, energy intake, parental overweight, protein, } \\
\text { soda, fruit and vegetables }\end{array}$ & $\leftrightarrow$ \\
\hline $\begin{array}{l}\text { Fisher et al. } \\
\qquad(2004)^{(48)}\end{array}$ & $\begin{array}{l}n 192 \text { (girls) } \\
\text { Age: } 5-9 \text { years, 4-year follow- } \\
\text { up } \\
\text { USA }\end{array}$ & $\begin{array}{l}\text { Dietary and } \\
\text { supplementary } \\
\mathrm{Ca}\end{array}$ & $\begin{array}{l}\text { There was no difference in BMI } z \text { score from age } 5 \text { to } \\
9 \text { years between the girls who met and those who } \\
\text { fell below the recommended adequate intake for } \\
\text { Ca }(P=0.83) \text { despite the higher energy intake in } \\
\text { those who met the recommendation }\end{array}$ & Pubertal status & $\leftrightarrow$ \\
\hline $\begin{array}{l}\text { Rockell et al. } \\
\qquad(2004)^{(50)}\end{array}$ & $\begin{array}{l}n 46 \text { ( } 18 \text { boys) } \\
\text { Age: } 6-10 \text { years, } 2 \text {-year } \\
\text { follow-up } \\
\text { New Zealand }\end{array}$ & Milk & $\begin{array}{l}\text { Non-milk consumers had higher BMI } z \text { scores at } \\
\text { baseline and } 33 \% \text { of the children were overweight } \\
\text { or obese at the } 2 \text {-year follow-up compared with the } \\
\text { reference population }(P<0.01)\end{array}$ & Unadjusted & $\downarrow$ \\
\hline $\begin{array}{l}\text { Newby et al. } \\
\quad(2004)^{(165)}\end{array}$ & $\begin{array}{l}n 1345 \text { ( } 675 \text { boys) } \\
\text { Age: } 2-5 \text { years, } 8 \text {-month } \\
\text { follow-up } \\
\text { USA }\end{array}$ & Milk & $\begin{array}{l}\text { There was no association between milk consumption } \\
\text { and annual change in weight and BMl } z \text { scores } \\
(\beta 0.00 \text { (SE } 0.01) ; P=0.84)\end{array}$ & $\begin{array}{l}\text { Age, sex, birth weight, energy intake, sociodemographic } \\
\text { variables, height change }\end{array}$ & $\leftrightarrow$ \\
\hline $\begin{array}{l}\text { Dixon et al. } \\
\qquad(2005)^{(47)}\end{array}$ & $\begin{array}{l}n 342 \text { ( } 171 \text { boys) } \\
\text { Age: } 4-10 \text { years, } 1 \text {-year } \\
\text { follow-up } \\
\text { USA }\end{array}$ & $\begin{array}{l}\text { Dietary Ca and } \\
\text { total dairy } \\
\text { products }\end{array}$ & $\begin{array}{l}\text { There were no associations between dietary } \mathrm{Ca} \\
\text { intake over a year and measures of adiposity in all } \\
\text { age groups in hypercholesterolaemic children } \\
(P>0.05) \text {. However, Ca intake was inversely } \\
\text { associated with } \mathrm{BMI}, \text { sum of skinfolds and trunk } \\
\text { skinfolds in the 7- to 10-year-old non- } \\
\text { hypercholesterolaemic children }\end{array}$ & Age, sex, time period, energy intake and fat & $\begin{aligned} \leftrightarrow & (\mathrm{HC}) \\
& \downarrow \text { (Non- } \\
& \mathrm{HC})\end{aligned}$ \\
\hline $\begin{array}{l}\text { Berkey et al. } \\
\qquad(2005)^{(41)}\end{array}$ & $\begin{array}{l}n 12829 \text { ( } 5550 \text { boys) } \\
\text { Age: } 9-14 \text { years, } 4 \text {-year } \\
\text { follow-up } \\
\text { USA }\end{array}$ & $\begin{array}{l}\text { Milk (full fat, } 2 \% \\
\quad \text { and } 1 \% \text { fat) }\end{array}$ & $\begin{array}{l}\text { High milk consumption ( } \geq 3 \text { servings } / \mathrm{d} \text { ) was } \\
\text { associated with higher BMl compared with low } \\
\text { milk consumption }(\leq 0.5 \text { servings/d) in both boys } \\
(\beta 0.08(\mathrm{SE} 0.04) ; P=0.04) \text { and girls }(\beta 0.09 \\
\text { (SE } 0.03) ; P=0.007)\end{array}$ & $\begin{array}{l}\text { Age, dietary factors, ethnicity, height growth, prior BMI } z \text { score, } \\
\text { Tanner stage, menarche, physical activity and inactivity }\end{array}$ & $\uparrow$ \\
\hline $\begin{array}{l}\text { Faith et al. } \\
\qquad(2006)^{(166)}\end{array}$ & $\begin{array}{l}n 971 \text { ( } 517 \text { boys) } \\
\text { Age: } 1-5 \text { years, } 4 \text {-year follow- } \\
\text { up } \\
\text { Australia }\end{array}$ & $\begin{array}{l}\text { Milk ( } 2 \% \text { or whole } \\
\text { fat) }\end{array}$ & $\begin{array}{l}\text { There was no association between increased milk } \\
\text { intake and excess adiposity gain (BMl } z \text { score of } \\
\beta-0.002 \text { (SE } 0.002 \text { ); } P=0.39 \text { ) }\end{array}$ & $\begin{array}{l}\text { Baseline child's weight-for-height } z \text { score, sex, race/ethnicity, } \\
\text { children's food and beverage intake, parental feeding styles } \\
\text { and attitudes variables }\end{array}$ & $\leftrightarrow$ \\
\hline $\begin{array}{l}\text { Moore et al. } \\
\quad(2006)^{(55)}\end{array}$ & $\begin{array}{l}n 92 \text { ( } 56 \text { boys) } \\
\text { Age: } 3-6 \text { years, } 8 \text {-year follow- } \\
\text { up } \\
\text { USA }\end{array}$ & $\begin{array}{l}\text { Total dairy } \\
\text { products }\end{array}$ & $\begin{array}{l}\text { Low dairy product consumption }(<1.75 \text { servings } / \mathrm{d}) \\
\text { was associated with greater subcutaneous fat } \\
(25 \mathrm{~mm} ; P=0.005) \text { and higher BMI ( } 2 \text { units; }\end{array}$ & $\begin{array}{l}\text { Age, physical activity, maternal education, baseline } \\
\text { anthropometry, saturated fat, energy intake }\end{array}$ & $\downarrow$ \\
\hline
\end{tabular}


Table 1 Continued

\begin{tabular}{|c|c|c|c|c|c|}
\hline Reference & Details & Exposure & Results and conclusion & Adjustment & Effect \\
\hline & & & $\begin{array}{l}P=0.046 \text { ) by the time of early adolescence } \\
\text { compared with high dairy product consumption }\end{array}$ & & \\
\hline $\begin{array}{l}\text { Striegel-Moore } \\
\quad \text { et al. }(2006)^{(51)}\end{array}$ & $\begin{array}{l}n 2371 \text { (girls) } \\
\text { Age: } 9-10 \text { years, 10-year } \\
\quad \text { follow-up } \\
\text { USA }\end{array}$ & Milk & $\begin{array}{l}\text { BMI decreased by } \beta-0.002 \text { (SE } 0.006 \text { ) units for every } \\
100 \mathrm{~g} \text { of milk (plain or flavoured) although not } \\
\text { statistically significant }(P>0.05)\end{array}$ & Race, site, visit, other beverages and energy intake & $\leftrightarrow$ \\
\hline $\begin{array}{l}\text { Tam et al. } \\
\quad(2006)^{(167)}\end{array}$ & $\begin{array}{l}n 281 \text { ( } 141 \text { boys) } \\
\text { Age: mean } 7 \cdot 7 \text { (SD } 0.6) \text { years, } \\
4.0-6 \cdot 6 \text { years follow-up } \\
\text { Australia }\end{array}$ & Milk & $\begin{array}{l}\text { There was no association between milk consumption } \\
\text { at baseline and BMI status at follow-up }(P=0.995)\end{array}$ & Unadjusted & $\leftrightarrow$ \\
\hline $\begin{array}{l}\text { Johnson et al. } \\
\qquad(2007)^{(168)}\end{array}$ & $\begin{array}{l}n 362 \text {, age } 5 \text { years } \\
n 471 \text {, age } 7 \text { years, } 2-4 \text { years } \\
\text { follow-up } \\
\text { UK }\end{array}$ & Milk & $\begin{array}{l}\text { There was an inverse association between milk } \\
\text { consumption at } 5 \text { or } 7 \text { years of age }(-0.51(95 \% \mathrm{Cl} \\
-0.86,-0.16) ; P<0.01) \text { and fatness at } 9 \text { years } \\
(-0.35(95 \% \mathrm{Cl}-0.57,-0.14) ; P<0.01)\end{array}$ & $\begin{array}{l}\text { Age, sex, BMI at baseline, height at } 9 \text { years, television viewing, } \\
\text { maternal education, paternal class and BMI, energy intake } \\
\text { misreporting, energy density, dietary factors }\end{array}$ & $\downarrow$ \\
\hline $\begin{array}{l}\text { Günther et al. } \\
\qquad(2007)^{(139)}\end{array}$ & $\begin{array}{l}n 203 \text { (102 boys) } \\
\text { Age: } 6 \text { months, } 7 \text {-year } \\
\text { follow-up } \\
\text { Germany }\end{array}$ & Dairy protein & $\begin{array}{l}\text { Higher dairy protein consumption (\% of energy) at } \\
\text { age } 12 \text { months was positively associated with } \\
\text { BMI-SDS at } 7 \text { years of age (T1: } 0.03(95 \% \\
\text { Cl }-0.21,0.27) \text { v. T3: } 0.35 \text { (95\% Cl } 0.13,0.57) \text {; } \\
P=0.02)\end{array}$ & $\begin{array}{l}\text { Sex, maternal overweight, maternal education, protein, fat, } \\
\text { fibre, energy intake, siblings in the dataset, firstborn status, } \\
\text { smoking in the house, baseline BMI-SDS and \%BF }\end{array}$ & $\uparrow$ \\
\hline Barr $(2007)^{(49)}$ & $\begin{array}{l}n 45 \text { (girls) } \\
\text { Age: mean } 10.5 \text { (sD } 0.6 \text { ) years, } \\
\text { 2-year follow-up } \\
\text { Canada }\end{array}$ & $\begin{array}{l}\text { Dietary and } \\
\text { supplementary } \\
\text { Ca }\end{array}$ & $\begin{array}{l}\text { There was no association between Ca consumption } \\
\text { and 2-year changes in \%BF and \% trunk fat in girls } \\
(P>0.05)\end{array}$ & Unadjusted & $\leftrightarrow$ \\
\hline $\begin{array}{l}\text { Kral et al. } \\
\quad(2008)^{(169)}\end{array}$ & $\begin{array}{l}n 49 \\
\text { Age: } 3-6 \text { years, 3-year follow- } \\
\text { up } \\
\text { USA }\end{array}$ & $\begin{array}{l}\text { Energy } \\
\text { consumed from } \\
\text { milk at ages } \\
3-5 \text { years }\end{array}$ & $\begin{array}{l}\text { Greater increases in energy consumed from milk } \\
\text { were inversely related to changes in children's } \\
\text { waist circumference }(\beta-0.01 \text { (SE } 0.004) ; P=0.04)\end{array}$ & $\begin{array}{l}\text { Change in waist circumference from ages } 3 \text { to } 5 \text { years and } \\
\text { total energy intake at age } 3 \text { years }\end{array}$ & $\downarrow$ \\
\hline $\begin{array}{l}\text { Fiorito et al. } \\
\qquad(2009)^{(170)}\end{array}$ & $\begin{array}{l}n 170 \text { (girls) } \\
\text { Age: } 5 \text { years, 10-year follow-up } \\
\text { USA }\end{array}$ & Milk & $\begin{array}{l}\text { Milk consumption at } 5 \text { years of age was not } \\
\text { associated with greater adiposity or weight status } \\
\text { over a 10-year period }(P>0.05)\end{array}$ & Unadjusted & $\leftrightarrow$ \\
\hline $\begin{array}{l}\text { Huus et al. } \\
\qquad(2009)^{(171)}\end{array}$ & $\begin{array}{l}n 14224 \text { ( } 6866 \text { boys) } \\
\text { Age: } 2 \cdot 5 \text { years, } 2 \cdot 5 \text {-year } \\
\text { follow-up } \\
\text { Sweden }\end{array}$ & $\begin{array}{l}\text { Cream/crème } \\
\text { fraîche, } \\
\text { cheese, ice- } \\
\text { cream }\end{array}$ & $\begin{array}{l}\text { Cheese consumption at } 2.5 \text { years of age was } \\
\text { positively while cream/crème fraîche was inversely } \\
\text { associated with overweight or obesity at } 5 \text { years of } \\
\text { age }\end{array}$ & $\begin{array}{l}\text { Mother's education and BMI, father's education and BMI, } \\
\text { heredity of diabetes, vegetables, potatoes, fried potatoes, } \\
\text { eggs, sausage, chocolate, candies, porridge }\end{array}$ & $\begin{array}{l}\uparrow \text { (Cheese) } \\
\downarrow \text { (Cream) }\end{array}$ \\
\hline $\begin{array}{l}\text { Vanselow et al. } \\
\quad(2009)^{(36)}\end{array}$ & $\begin{array}{l}\text { n } 2294 \text { (1032 boys) } \\
\text { Age: mean } 14 \cdot 9 \text { (SD } 0 \cdot 1) \text { years, } \\
\text { 5-year follow-up } \\
\text { USA }\end{array}$ & Milk & $\begin{array}{l}\text { There was an inverse association between milk } \\
\text { consumption and mean weight gain over a } 5 \text {-year } \\
\text { period without displaying a dose-response } \\
\text { relationship }(0 \text { servings } / \text { week }=2.34 \text { (SE } 0.24) \mathrm{kg} v \text {. } \\
0.5-6 \text { servings/week }=1.68(\mathrm{SE} 0.11) \mathrm{kg} v .>7 \\
\text { servings/week }=1.93 \text { (SE } 0.11) \mathrm{kg} ; P=0.03 \text { ) }\end{array}$ & $\begin{array}{l}\text { Age, sex, race/ethnicity, socio-economic status, baseline BMI, } \\
\text { physical activity, television viewing, beverage, coffee and tea } \\
\text { intake }\end{array}$ & $\downarrow$ \\
\hline $\begin{array}{l}\text { Huh et al. } \\
\qquad(2010)^{(39)}\end{array}$ & $\begin{array}{l}n 852 \text { ( } 466 \text { boys) } \\
\text { Age: } 2 \text { years, } 1 \text {-year follow-up } \\
\text { USA }\end{array}$ & $\begin{array}{l}\text { Dairy products } \\
\text { and milk (full- } \\
\text { fat and } \\
\text { reduced-fat) }\end{array}$ & $\begin{array}{l}\text { There was no association between dairy product or } \\
\text { milk (either full- or reduced-fat) consumption at } 2 \\
\text { years of age and BMI } z \text { score or with the risk of } \\
\text { incident overweight at age } 3 \text { years }(P>0.05)\end{array}$ & $\begin{array}{l}\text { Age, sex, race/ethnicity, baseline BMI z score, energy intake, } \\
\text { non-dairy beverage intake, television viewing, maternal BMI } \\
\text { and education, paternal BMI }\end{array}$ & $\leftrightarrow$ \\
\hline $\begin{array}{l}\text { Noel et al. } \\
\qquad(2011)^{(38)}\end{array}$ & $\begin{array}{l}n 2245 \text { (1030 boys) } \\
\text { Age: } 10 \text { years, } 1-3 \text { years } \\
\text { follow-up } \\
\text { UK }\end{array}$ & $\begin{array}{l}\text { Milk (full-fat and } \\
\text { reduced-fat) }\end{array}$ & $\begin{array}{l}\text { There was no association between milk consumption } \\
\text { at age } 10 \text { years and BF at } 13 \text { years of age }(\beta-0.15 \\
\text { (95\% } \mathrm{Cl}-0.52,0.23) ; P=0.45) \text {. Changes in milk } \\
\text { consumption from } 10 \text { to } 13 \text { years of age were not } \\
\text { associated with changes in \%BF from } 11 \text { to } 13 \\
\text { years of age }\end{array}$ & $\begin{array}{l}\text { Age, sex, height, physical activity, pubertal status, maternal } \\
\text { BMI and education, fat, sugar-sweetened beverages, } \\
\text { cereals, energy intake and baseline BMI }\end{array}$ & $\leftrightarrow$ \\
\hline
\end{tabular}




\begin{tabular}{|c|c|c|c|c|c|}
\hline Reference & Details & Exposure & Results and conclusion & Adjustment & Effect \\
\hline $\begin{array}{l}\text { Garden et al. } \\
\quad(2011)^{(32)}\end{array}$ & $\begin{array}{l}n 362 \text { (183 boys) } \\
\text { Age: } 18 \text { months, } 8 \text {-year } \\
\text { follow-up } \\
\text { Australia }\end{array}$ & $\begin{array}{l}\text { Total dairy } \\
\text { products }\end{array}$ & $\begin{array}{l}\text { Higher consumption of dairy products }(\% \text { of total } \\
\text { energy) was inversely associated with BMI at } 8 \\
\text { years }(\beta-0.21(95 \% \mathrm{Cl}-0.41,0.01) ; P=0.04)\end{array}$ & $\begin{array}{l}\text { Sex, asthma study intervention group, birth weight, breast- } \\
\text { feeding for } 6 \text { months, parental obesity status, ethnicity, } \\
\text { smoking in pregnancy, paternal education }\end{array}$ & $\downarrow$ \\
\hline $\begin{array}{l}\text { Lin et al. } \\
\quad(2012)^{(172)}\end{array}$ & $\begin{array}{l}n 5968 \text { (2900 boys) } \\
\text { Age: } 11 \text { years, 2-year } \\
\text { follow-up } \\
\text { China }\end{array}$ & Milk & $\begin{array}{l}\text { There was no association between milk consumption } \\
\text { at } 11 \text { years and BMl } z \text { score at approximately } 13 \\
\text { years of age }(\beta-0.01(95 \% \\
\mathrm{Cl}-0.07,0.05) ; P=0.65)\end{array}$ & $\begin{array}{l}\text { Sex, baseline BMI } z \text { score, birth order, maternal age and } \\
\text { mother's birthplace, highest parental education, physical } \\
\text { activity, vegetable, fruit and soft drink intakes }\end{array}$ & $\leftrightarrow$ \\
\hline $\begin{array}{l}\text { Rangan et al. } \\
\qquad(2012)^{(31)}\end{array}$ & $\begin{array}{l}n 335 \text { ( } 169 \text { boys) } \\
\text { Age: } 16-24 \text { months, } 7 \cdot 7-9 \cdot 2 \\
\text { years follow-up } \\
\text { Australia }\end{array}$ & $\begin{array}{l}\text { Total dairy } \\
\text { products }\end{array}$ & $\begin{array}{l}\text { There was no association between dairy product } \\
\text { consumption at } 18 \text { months and BMl at age } 8 \text { years } \\
(P=0.09)\end{array}$ & Unadjusted & $\leftrightarrow$ \\
\hline $\begin{array}{l}\text { Noel et al. } \\
\qquad(2013)^{(35)}\end{array}$ & $\begin{array}{l}n 2270 \text { (1028 boys) } \\
\text { Age: } 10 \text { years, } 1-3 \text { years } \\
\text { follow-up } \\
\text { UK }\end{array}$ & Flavoured milk & $\begin{array}{l}\text { Flavoured milk consumption at age } 10 \text { years was } \\
\text { associated with smaller reduction in \% } \mathrm{BF} \text { in } \\
\text { overweight/obese children from ages } 11 \text { to } 13 \\
\text { years compared with the non-flavoured milk } \\
\text { consumption }(-0.79(95 \% \mathrm{Cl}-2 \cdot 46,-0.88) \\
v .-2 \cdot 19(95 \% \mathrm{Cl}-3.60,-0.78) ; P=0.02 \\
\text { respectively) }\end{array}$ & $\begin{array}{l}\text { Age, sex, height, height }{ }^{2} \text {, baseline BMI, physical activity, } \\
\text { pubertal status, maternal BMI and education, fat, cereal, } \\
\text { fruit, vegetable, sugar-sweetened, milk and energy intakes }\end{array}$ & $\leftrightarrow$ \\
\hline $\begin{array}{l}\text { Scharf et al. } \\
\quad(2013)^{(40)}\end{array}$ & $\begin{array}{l}n 8300 \text { ( } 4200 \text { boys) } \\
\text { Age: } 4 \text { years, } 2 \text {-year } \\
\text { follow-up } \\
\text { USA }\end{array}$ & $\begin{array}{l}\text { Milk (full-fat and } \\
\text { reduced-fat) }\end{array}$ & $\begin{array}{l}\text { There was no association between either full- or } \\
\text { reduced-fat milk at age } 4 \text { years in the change in } \\
\text { BMI } z \text { score over the } 2 \text {-year follow-up }(P=0.6)\end{array}$ & Sex, race/ethnicity, socio-economic status & $\leftrightarrow$ \\
\hline $\begin{array}{l}\text { Hasnain et al. } \\
\qquad(2014)^{(53)}\end{array}$ & $\begin{array}{l}n 103 \\
\text { Age: } 3-5 \text { years, 12-year } \\
\text { follow-up } \\
\text { USA }\end{array}$ & Milk & $\begin{array}{l}\text { Higher milk consumption at ages } 3-9 \text { years was } \\
\text { negatively associated with \%BF at ages } 15-17 \\
\text { years (T1, 30\% v. T3, 22.6\%; } P=0.009)\end{array}$ & $\begin{array}{l}\text { Age, baseline anthropometry, fat, television viewing, beverage } \\
\text { intake, maternal BMI and education }\end{array}$ & $\downarrow$ \\
\hline $\begin{array}{l}\text { DeBoer et al. } \\
\qquad(2014)^{(54)}\end{array}$ & $\begin{array}{l}n 8950 \text { ( } 4550 \text { boys) } \\
\text { Age: } 4 \text { years, } 1 \text {-year follow-up } \\
\text { USA }\end{array}$ & Milk & $\begin{array}{l}\text { There was no association between milk consumption } \\
\text { at } 4 \text { years and BMl } z \text { score }(P=0.79) \text { or weight-for- } \\
\text { height } z \text { score }(P=0.24) \text { at age } 5 \text { years }\end{array}$ & Sex, race/ethnicity, socio-economic status and milk type & $\leftrightarrow$ \\
\hline $\begin{array}{l}\text { Bigornia et al. } \\
\qquad(2014)^{(42)}\end{array}$ & $\begin{array}{l}n 2455 \text { ( } 1154 \text { boys) } \\
\text { Age: } 10 \text { years, 3-year follow-up } \\
\text { UK }\end{array}$ & $\begin{array}{l}\text { Dairy products } \\
\text { (full-fat and } \\
\text { reduced-fat) }\end{array}$ & $\begin{array}{l}\text { High full-fat dairy product consumption at age } 10 \\
\text { years was associated with lower risk of total } \mathrm{BF} \\
\text { mass at } 13 \text { years (OR } 0.64(95 \% \mathrm{Cl} 0.40,1.00) \text {; } \\
P=0.04)\end{array}$ & $\begin{array}{l}\text { Age, sex, height, total dairy products at } 13 \text { years, adiposity at } \\
10 \text { years, maternal education and overweight status, } \\
\text { physical activity, pubertal stage and dieting }\end{array}$ & $\begin{array}{l}\leftrightarrow \text { (Dairy } \\
\text { products) } \\
\downarrow \text { (Full-fat } \\
\text { dairy } \\
\text { products) }\end{array}$ \\
\hline $\begin{array}{l}\text { Braun et al. } \\
\quad(2016)^{(140)}\end{array}$ & $\begin{array}{l}n 3564 \text { (1748 boys) } \\
\text { Age: } 12 \text { months, } 8 \text {-year } \\
\text { follow-up } \\
\text { Netherlands }\end{array}$ & Dairy protein & $\begin{array}{l}\text { A } 10 \mathrm{~g} \text { higher total dairy protein intake/d at } 1 \text { year } \\
\text { was associated with a } 0.07-\mathrm{sD} \text { increase in weight } \\
(95 \% \mathrm{Cl} 0.03,0.012 ; P<0.05) \text { and a } 0.07-\mathrm{sD} \\
\text { increase in } \mathrm{BMI}(95 \% \mathrm{Cl} 0.02,0.11) \text { at } 9 \text { years. } \\
\text { Similar effect size for non-dairy food sources }\end{array}$ & $\begin{array}{l}\text { Birth weight } z \text { score, breast-feeding, playing sports, household } \\
\text { income, and maternal BMI at enrolment, education, folic } \\
\text { acid use during pregnancy, smoking during pregnancy and } \\
\text { non-dairy animal protein }\end{array}$ & $\uparrow$ \\
\hline $\begin{array}{l}\text { Dubois et al. } \\
\qquad(2016)^{(43)}\end{array}$ & $\begin{array}{l}n 152 \text { twin pairs } \\
\text { Age: } 9 \text { years, } 5 \text {-year follow-up } \\
\text { Canada }\end{array}$ & $\begin{array}{l}\text { Milk (full-fat and } \\
\text { reduced-fat) }\end{array}$ & $\begin{array}{l}\text { Milk consumption at } 9 \text { years was positively } \\
\text { associated with BMI change from } 9 \text { to } 14 \text { years. } \\
\text { Reduced-fat milk was positively associated with } \\
\text { BMI change in girls }\end{array}$ & Unadjusted & $\begin{array}{l}\uparrow \text { (Milk) } \\
\uparrow \\
\text { (Reduced- } \\
\text { fat milk for } \\
\text { girls) }\end{array}$ \\
\hline
\end{tabular}

\%BF, percentage body fat; $\mathrm{BF}$, body fat; $\downarrow$, negative association between exposure (dairy products) and a measure of body fatness; $\leftrightarrow$, null association between exposure (dairy products) and a measure of body fatness; HC, hypercholesterolaemic; non-HC, normocholesterolaemic; $\uparrow$, positive association between exposure (dairy products) and a measure of body fatness; SDS, standard deviation score; T1, tertile 1; T3, tertile 3. 
the broad range of readers who may be interested in the work. However, it is important to note that it is not appropriate to 'add up the arrows' within each study design to assess the balance of evidence since this would ignore sample size, statistical power of each study, and how heavily each study should be weighted in considering the overall evidence base. For example, ten $\uparrow$ studies plus one $\downarrow$ study plus five $\leftrightarrow$ studies cannot be interpreted as a summary finding of a statistically significant positive effect/relationship between dairy milk and other milk products and obesity. We appreciate that if we had conducted a systematic review and assessed each included study for quality (based on design and implementation), and combined the results in a meta-analysis, then each individual study's findings would contribute to the overall (summary) effect size, and this would be an appropriate way to assess the balance of evidence.

\section{Evidence from cross-sectional studies ( $n$ 43) of the associations between dairy product intake and body weight in children and adolescents}

As a starting point to our research, and also for completeness, we reviewed the evidence reported from cross-sectional studies (online Supplementary Table S3). Forty-three cross-sectional studies were identified for this review. Studies were included from across the globe resulting in thirteen from Europe, fifteen from the USA, five from Middle Eastern countries, four from South American countries, two from Australia, two from South East Asia and two from Canada. The numbers of participants in the cross-sectional studies ranged from 114 to 7557 and included girls and boys at a specific point in time. The age of subjects ranged from 2 to 19 years; however, most studies covered school-age children and adolescents. Results varied greatly in girls and boys and by age group and by type of dairy product.

Two studies were identified showing an association between dairy product intake and increased levels of obesity or indicators of adiposity (one in boys only), whereas all others showed either a null association or inverse association by sex, age group or type of dairy product. In order to explore for reasons for the different results, we looked for themes which might offer an explanation, including type of measurements used, age, race, location, classification of milk and dairy product used, type of dairy product, difference in diets, methodological quality of the study including data analysis, and whether the authors had adjusted for energy and other confounders. We could not identify any consistent reasons for the different results between studies, but detail a summary description of the two crosssectional studies which found that dairy food intake was associated with increased obesity or indicators of adiposity below, for completeness.

Nezami et al. ${ }^{(29)}$ assessed whether dairy product consumption was associated with anthropometric indicators of health in 536 subjects ( 231 males and 305 females) with a mean age of 14.99 years in a culturally diverse population (37\% Caucasian, $15 \%$ Hispanic, 13\% Asian/Pacific Islander, 10\% African/African American, and $25 \%$ with mixed or other ethnicities). Total dairy product (milk, cheese and sweetened dairy products) consumption was positively and significantly associated with fat mass, fat-free mass and waist:height ratio in males but not in females. Cheese intake was significantly higher in boys compared with girls $(2 \cdot 1$ (SD 1.3) servings and 1.7 (SD 1.1) servings, respectively). Normal-weight males consumed more milk than their overweight or obese counterparts but less dairy food in total. The authors adjusted their analysis for age, sex, ethnicity, education of mother, and energy intake, soda intake, physical activity, and milk substitutes intake.

Wiley $^{(30)}$ analysed National Health and Nutrition Examination Survey data from 1999 to 2004 and suggested that a dietary pattern characterised by greater milk consumption was associated with increased BMI among children aged $2-10$ years, and dairy product intake among 2- to 4-year-old children. The sample included 1493 participants, of which 68\% were Caucasian, 15\% Hispanic and 15\% African/African American. The authors adjusted their analysis for age, birth weight and ethnicity.

We understand that the associations between the exposure (milk and other dairy product consumption) and outcome (body weight/composition) may reflect reverse causality, which means that the presence of adiposity in children may affect their dairy product consumption habits. Contrary to cross-sectional studies, longitudinal analysis of prospective cohort studies represents a more robust design that allows the study of determinants (in this case, milk and other dairy products) with changes over time in measures of adiposity.

\section{Evidence from longitudinal studies ( $n$ 31) of the associations between dairy product intake and body weight in children and adolescents}

A total of thirty-one studies were identified for review; the size of the cohorts ranged from forty-five to 12829 and the duration of the follow-up from 8 months to 12 years covering all the periods of growth and human development from infancy to adolescence (Table 1). Of the thirty-one studies, seventeen showed no associations between dairy product, milk or Ca consumption and BMI or measures of adiposity. Rangan et al. ${ }^{(31)}$ showed null associations between the high and the low quartiles of energy-adjusted dairy product consumption at 18 months and BMI or weight at 8 years $(P=0.09)$ in 335 children from the longitudinal Childhood Asthma Prevention Study (CAPS). However, Garden et al. ${ }^{(32)}$ using the same CAPS population after adjusting for potential confounders showed that dairy product consumption (compared with protein, meat and fruit consumption) as a percentage of total energy was inversely associated with BMI $(P=0.04)$ and waist circumference $(P=0.09)$ at 8 years of age, highlighting that lack of adequate control for potential confounding could have led to conflicting results observed in children. Despite the rigorous assessment of diet at 18 months, intake might not be reflective of the habitual food diet over the entire follow-up period. Phillips et $a l .{ }^{(33)}$ conducted the first longitudinal analysis in which they considered the pattern of change in dairy product consumption and body weight or fatness during adolescence using annual follow-up assessments of body composition and dietary intake over a 10-year period. After adjusting for 
covariates, results indicated a null association between dairy product consumption and BMI $z$ score $(\beta=0.017 ; P=0.65)$ or percentage body fat $(\beta=0 \cdot 18 ; P=0.51)$ in 178 initially normalweight preadolescent girls.

\section{Differences by type of milk and other dairy products}

The majority of prospective studies have examined only milk; thus the impact of 'type' of dairy products on the associations between dairy product consumption and body composition remains largely unknown.

With respect to type of milk and the effects of added sugar on health, Fayet-Moore ${ }^{(34)}$ recently reviewed the literature related to the role of flavoured or sweetened milk in the diet and weight status of children. Although flavoured milk has similar fat and protein content to white milk, it provides approximately $60 \mathrm{kcal}(250 \mathrm{~kJ})$ more per serving portion than plain milk due to added sugars ${ }^{(35)}$. Two prospective studies have examined the relationship between milk and measures of adiposity, by differentiating between white milk and flavoured milk ${ }^{(35,36)}$ A beneficial association of white milk with body weight was reported in the Project EAT (Eating Among Teens) by Vanselow et $a l .{ }^{(36)}$. The authors showed that plain milk and not flavoured milk consumption assessed by FFQ was inversely related to weight gain (self-assessed) over the 5-year follow-up ( $P=0.05$ v. $P=0 \cdot 31)$ without displaying a dose-response relationship in 2294 adolescents and independent of their overweight status. A more recent study employed more accurate measures of dietary intake and body composition by using dietary weighed records and dual-energy X-ray absorptiometry in 2270 children at the age of 10 years ${ }^{(35)}$. Results showed that the decrease in percentage body fat was less in overweight/obese children who consumed flavoured milk (17\%) than non-consumers of flavoured milk (83\%) (-0.16 (95\% CI -3.8, 3.5) v. -3.4 (95\% CI $-6 \cdot 5,-0.42) \% ; P=0 \cdot 02)$. However, there was no association between flavoured milk consumption at 10 years and change in percentage body fat from 11 to 13 years in normal-weight children. It is worth noting that this was the only study that has examined whether the subjects' BMI at baseline could influence the association between dairy product consumption and body weight or abdominal obesity during childhood or adolescence.

Overall, although the body of literature on flavoured milk is limited, according to the review by Fayet-Moore ${ }^{(34)}$ consumption of flavoured milk is not related to weight gain or increased body fat among normal-weight children. However, there are conflicting and inconsistent results among overweight and obese children; thus randomised intervention studies are warranted to examine the effect of flavoured milk consumption on BMI and adiposity. Given the popularity of flavoured milk as the preferred dairy product amongst children, controlled studies with better description of exposure and outcome variables are needed.

\section{Low-fat v. full-fat dairy products}

Given the scientific interest on the issue of dairy fat and its contribution to the development of obesity due its high energy content $^{(37)}$, we explored the data to assess whether there was any evidence of differential associations of low- and full-fat milk with weight status. Five of the six longitudinal studies examined the relationship between low- or full-fat milk and other dairy products on obesity and indicators of adiposity as a primary outcome of their analysis ${ }^{(38-43)}$. Although evidence is limited, data suggest that replacing whole milk with reduced-fat milk does not lead to an inverse or positive association between milk and weight gain or prevention of overweight in early childhood. For instance, in 10- to 13-year-olds, Noel et al. ${ }^{(38)}$ showed that there was no significant difference between low-fat or skimmed milk $v$. whole milk at 10 years and change in percentage body fat $(P>0.09)$ at 11 and 13 years. In preschool children, Huh et $a l .{ }^{(39)}$ reported inverse association between whole milk, but not low-fat milk, consumption at age 2 years and BMI $z$ score $(\beta=-0.09$ (95\% CI $-0 \cdot 16,-0 \cdot 01) ; P=0.02)$ at age 3 years in 852 children, yet there was no association between either whole or low-fat milk with incidence of overweight at age 3 years. Similarly, Scharf et al. ${ }^{(40)}$ showed in a longitudinal analysis examining 10700 children that milk consumption at age 2 years, whether whole or low-fat, was not related to changes in BMI $z$ score at the age of 4 years $(P=0 \cdot 6)$. However, children who were normal weight at baseline and consistently drank $1 \%$ fat or skimmed milk at both 2 and 4 years of age had an increased risk of becoming overweight or obese during this time interval (OR 1.57 (95\% CI 1.03, 2.42); $P<0.05)$. This contradicts the current American Academy of Pediatrics recommendation in favour of low-fat milk consumption at children $\geq 2$ years ${ }^{(44)}$, yet the results could be related to residual confounders that have not been assessed in their analysis such as other food items, total energy intake and physical activity. Berkey et al. ${ }^{(41)}$ evaluated the association between annual milk consumption and BMI changes and found that in 12829 children aged 9-14 years, those drinking $\geq 3$ servings of milk per $\mathrm{d}$ had a significantly higher increase in BMI over 4 years, compared with those drinking $>1$ and $\leq 2$ servings per $d$. Particularly, high consumption of $1 \%$ milk for boys and skimmed milk for girls had more consistent positive associations with annual BMI gain than did whole or $2 \%$ milk $(P<0.05)$. However, adjustment for multiple variables revealed that total energy intake mediated those associations, contributing to the heavier weight status.

\section{Can dietary calcium reduce body weight?}

As dairy products represent the major source of dietary $\mathrm{Ca}$, a few studies reported on the association between dietary $\mathrm{Ca}$ and adiposity, without a clear distinction between dairy and nondairy Ca sources. Nevertheless, as far as Ca is concerned, three studies suggested an inverse relationship between dietary Ca consumption and prevalence of obesity and adiposity in children ${ }^{(45-47)}$. Skinner et al. $^{(46)}$ suggested that increasing the $\mathrm{Ca}$ intake with $240 \mathrm{ml}$ skimmed milk or yoghurt daily would reduce children's body fat by $0.4 \%$, which in the longer term could reduce the risk of obesity in later childhood, adolescence or adulthood. However, several studies, conducted mostly in girls, showed that dietary Ca over the years was not associated with BMI $z$ scores, percentage body fat or trunk fat during adolescence $^{(33,48-50)}$. Very few studies have evaluated the relationship 
of dietary Ca and adiposity according to sex or ethnicity $(45,47,51)$ and differences in terms of inherent sex characteristics, growth, pubertal status and sexual maturation ${ }^{(52)}$ add complexity to the impact of sex on $\mathrm{Ca}$-adiposity associations.

\section{Differences by age of child}

Hasnain et $a l .{ }^{(53)}$ conducted the longest study using data from the Framingham Children's Study, in which 103 boys and girls aged 3-5 years old were enrolled and followed annually for 12 years. Prospective analysis between milk and percentage body fat (dual-energy X-ray absorptiometry) indicated that children in the highest tertile of milk consumption $(411 \mathrm{ml} / \mathrm{d})$ had $7 \cdot 3 \%$ lower percentage body fat compared with the lowest $(115 \mathrm{ml} / \mathrm{d}$; 30 v. $22.6 \% ; P=0.0095)$ at ages $15-17$ years. However, DeBoer et $a l{ }^{(54)}$ recently found that in 4 -year-old children, drinking $\geq 4$ servings of milk daily had a higher risk of becoming overweight compared with those with an intake of $<1$ serving daily at age 4 years (OR 1.159 (95\% CI 1.02, 1.32); $P=0.021$ ), yet the positive association was no longer present at 5 years (OR 1.094 (95\% CI $0.92,1.31) ; P=0.318)$. As the authors suggested, this minor adverse association of excess milk consumption with weight status could be age-dependent, with more pronounced association of milk consumption with height over time contrary to its association with weight gain.

\section{Discussion of longitudinal studies}

As summarised in Table 1, there are considerable differences in the exposure and outcome variables and population characteristics, with seventeen studies examining specifically the association between milk consumption and indicators of body weight or adiposity. Data from most prospective studies included in the present review showed that there is a null association between increased milk ( $n$ 9) or dairy product ( $n$ 5) consumption and measures of adiposity or body weight. However, there was high variation on the definition and inclusion of dairy foods and type of milks in the studies. For instance, considering the type of milk or fat content, a few studies followed the United States Department of Agriculture definition ${ }^{(15)}$ which includes white milk (cow, sheep or goat), while other studies also included sweetened and flavoured, evaporated, condensed, formula, reduced-fat, full-fat or non-fat milk. Similarly, there were notable differences among the seven stu$\operatorname{dies}^{(31-33,39,42,47,55)}$ that investigated total dairy products, with most including any type of yoghurt or cultured milk drinks and natural or processed cheese and some others including dairy desserts such as ice-cream, milkshakes, custard creams and puddings in addition to milk, yoghurt and cheese. However, there were no differences in adiposity outcomes between the studies that included dairy desserts and those that did not. Furthermore, four of them ${ }^{(32,33,39,42)}$ reported the portion or percentage energy from milk or other type of dairy products. Based on their reports, milk contributed approximately 50-70\% of the total dairy product consumption followed by yoghurt and cheese, particularly in the highest quartiles or groups of dairy product consumption. Although milk, cheese and yoghurt share several functional properties, differences in their absorption kinetics, macro- and micronutrient content and level of bioactive components could lead to different metabolic effects ${ }^{(56)}$. Thus, disaggregating the effects of individual types of dairy product consumption from general dairy products in large-scale epidemiological studies seems prudent.

Few longitudinal studies directly compared body weight or adiposity outcomes related to reduced-fat $v$. full-fat milk or dairy products and results suggest no significant differences between reduced-fat compared with full-fat milk or total dairy products and body weight or adiposity measures $^{(33,38-43)}$. Most of these studies were conducted in the US population and results could have been influenced by reporting bias or residual confounding due to the cultural perception related to fat consumption or other unmeasured associated dietary and health behaviours ${ }^{(57,58)}$. Additionally, the range or form that dairy food is consumed might differ, given that in the USA, dairy fat is usually consumed as icecream or dairy desserts, whilst in Europe plain cheeses or unsweetened yoghurt are the major source of full-fat dairy products $^{(37)}$. However, given the limited data, it makes it difficult to draw firm conclusions about whether reduced-fat or full-fat milk and other dairy product consumption may be more beneficial.

Most of the observational studies assessed milk and other dairy product consumption by FFQ, which, compared with food records ${ }^{(59)}$, are not the most accurate dietary assessment tool for certain foods, particularly foods that are perceived as unhealthy such as whole milk and cream ${ }^{(60)}$. Another acknowledged source of bias in any nutrition research is the over- and underreporting of dietary intakes, which could lead to gross misclassification of full-fat dairy product intake, particularly among overweight adolescents ${ }^{(61)}$. The accuracy of energy reporting may decline as children become older ${ }^{(62)}$; thus unbiased estimates of intake are more likely to occur when the dietary reporting is conducted by parents in early childhood (before the age of 6 years $)^{(55)}$. Although there is some evidence that milk consumption in childhood tracks over time ${ }^{(55,63,64)}$, a limitation within the longitudinal studies reviewed in the present study is the lack of regular assessment of dairy product and dietary intake throughout childhood and adolescence. The patterns with regard to the type of milk and other dairy product consumption might not be stable over time, especially with the introduction and higher availability of reduced-fat dairy products over the last 25 years.

In addition to diversity in describing the type or fat content of milk and other dairy products, there was variation on the definition and reporting of dairy food serving size, with some studies using the term 'serves per day', 'portions per day', 'grams per day' or 'times per day'. Similarly, considerable variation was found in the reporting of outcome variables related to weight status and adiposity measures, making it difficult to compare research findings. Future studies in this research area should include a set of well-defined exposure and outcome variables, measured ideally by health professionals to minimise error and reported in a consistent format. For instance, milk, cheese and yoghurt and the type of those dairy foods and fat content reported in $\mathrm{g}$ per $\mathrm{d}$ as an absolute serving size should be defined. Change in weight in children 
and adolescents should be reported as BMI $z$ score, body weight, percentage body fat, percentage lean body mass and waist circumference.

Adjustment for important confounding factors such as energy intake, diet quality, physical activity levels, baseline BMI, sex, race and socio-economic status were inconsistent and varied among the studies, making it difficult to interpret and compare the results across study cohorts. For instance, twenty-six of the thirty-one studies reviewed included data on both boys and girls, and only sixteen adjusted for sex. Similarly, five (35,38,41,42,48) of the fifteen studies, which analysed data in school-age children and adolescents, adjusted for pubertal growth development. This is important given that children and adolescents' body size and composition are influenced by the sex and pubertal growth rate, for example, change in height ${ }^{(65)}$, with notable differences in growth rate in the period from early childhood to adolescence. Thus, assumptions that the body composition measures would be independent of pubertal growth stage are invalid and both observational and controlled randomised trials need to consider the influence of pubertal development on the effect of milk and other dairy product consumption on indicators of adiposity. Furthermore, adjustment for energy intake needs to be carefully considered given the high degree of association between increased energy intake and adiposity ${ }^{(66)}$. As Berkey et al. ${ }^{(41)}$ highlighted, the positive association between milk and annual BMI gain was mediated by the total energy intake and not necessarily by the dairy products per se. Given that dairy products could influence body weight through mediating appetite, energy intake and therefore energy regulation as described in the mechanistic section below, analyses should be performed with and without energy intake in the adjustment models. Energy intake was reported in thirteen studies and five studies reported food groups or beverages or macronutrients as indicators of dietary intake in their adjustment models. Thus, inclusion and appropriate control of potential confounders is essential in analyses of all studies.

Sample size and duration varied significantly among the studies, with studies with a protective association between milk and other dairy products and obesity having a smaller sample size (nineteen studies $n<1000$, of which eight showed inverse association) relative to the studies reported an adverse association between increased milk and dairy product consumption and obesity (twelve studies $n>1000$, of which two showed an adverse association). One-third of the studies were funded by the dairy or private industry and five studies showed results favourable for industry compared with the four out of twentyone public-funded studies, which demonstrated a favourable effect for dairy foods and obesity risk. It is also worth noting that twenty-six out of the thirty-one studies were performed in English-speaking nations (USA ( $n$ 16), Australia ( $n$ 4), UK ( $n$ 4) and Canada ( $n$ 2)); thus results might not be generalisable to all developed and developing countries.

Overall, the majority of prospective studies showed a null relationship between increased dairy product consumption and measures of adiposity or body weight in children and adolescents with high relative to low or no dairy product consumption. Although data are limited, they suggest that replacing whole milk with reduced-fat milk does not lead to an inverse or positive association between milk and weight gain or prevention of overweight in early childhood.

Evidence from intervention studies ( $n$ 20) of the effect of milk and other dairy product intake, with or without energy restriction, on body composition in children

Human intervention studies represent the most robust source of evidence to explore 'cause-and-effect' relationships between dairy product consumption and measures of adiposity. Twenty randomised intervention studies examined the effect of dairy products, milk or Ca-rich diets on body weight, body composition and other measures of adiposity during childhood and adolescence. Of the twenty studies identified, ten had bone health as the primary endpoint, but body composition was accurately measured using a state-of-the art method of dualenergy X-ray absorptiometry in all of these studies. However, some of those studies may lack the statistical power needed to detect significant differences in body weight and body composition and therefore should be interpreted with caution. The characteristics and main outcomes of the twenty studies that investigated the effect of milk and other dairy product consumption on indicators of body weight and adiposity are displayed in chronological order in Table 2.

\section{What do studies that examined bone health reveal about body weight?}

The majority of the studies that were primarily designed to examine bone health failed to detect differences among the treatments ${ }^{(67-74)}$. For example, Chan et al. ${ }^{(67)}$ conducted a 12 -month randomised parallel study in pubertal girls and found no differences in body weight, lean body mass and fat mass between the high dairy $\mathrm{Ca}$ group (1200 $\mathrm{mg} \mathrm{Ca} / \mathrm{d}$ ) and the control group (usual diet). Likewise, Cadogan et al. ${ }^{(68)}$ reported no effect of whole or reduced-fat milk consumption $(568 \mathrm{ml} / \mathrm{d})$ on body composition in 12-year-old girls for 18 months, and Merrilees et al. ${ }^{(69)}$ found no effect with the provision of $1000 \mathrm{mg}$ $\mathrm{Ca} / \mathrm{d}$ from dairy foods over 2 years on body weight, body lean mass and fat mass in post-pubertal teenage girls compared with those girls on their usual diet. Similar neutral effects were observed in an 18-month randomised parallel study in 9- to 10year-old Chinese children, between the $80 \mathrm{~g}$ (equivalent to $250 \mathrm{ml}$ whole milk) or $40 \mathrm{~g}$ milk powder supplementation group and the control group (usual diet) ${ }^{(72)}$. A more recent 18-month randomised parallel study showed that 240 healthy-weight and overweight 8- to 16-year-old boys and girls when assigned to either receive three servings of dairy products/d $(1500 \mathrm{mg} \mathrm{Ca} / \mathrm{d})$ or maintain their usual diet $(1000 \mathrm{mg} \mathrm{Ca} / \mathrm{d})$ had no differences in body weight and fat gain ${ }^{(74)}$. In contrast, one study conducted in 757 Chinese girls with low habitual Ca diet and high prevalence of vitamin D deficiency showed weight gain and enhanced growth ${ }^{(75)}$. Du et al. ${ }^{(75)}$ conducted the largest schoolmilk intervention trial, where the 10 -year-old girls were randomly assigned to a group that received $330 \mathrm{ml}$ of Ca-fortified milk, a group that received $330 \mathrm{ml}$ of Ca-fortified milk plus 
Table 2. Randomised intervention studies $(n 20)$ of milk and other dairy product consumption on weight gain or body composition in children

\begin{tabular}{|c|c|c|c|c|c|}
\hline Reference & Details & Intervention & Results and conclusion & Adjustment & Effect \\
\hline Chan et al. $(1995)^{(67)}$ & $\begin{array}{l}n 48 \text { (girls) } \\
\text { Age: } 9-13 \text { years, } 12 \text { months } \\
\text { USA }\end{array}$ & $\begin{array}{l}\text { Diets: } \\
\text { (a) Dairy products ( } 1200 \mathrm{mg} \mathrm{Ca} / \mathrm{d} \text { ) } \\
\text { (b) Control (usual diet) }\end{array}$ & $\begin{array}{l}\text { Increased dairy product consumption over a year was } \\
\text { not associated with weight gain or increased \%BF }\end{array}$ & Unadjusted & $\leftrightarrow$ \\
\hline Cadogan et al. $(1997)^{(68)}$ & $\begin{array}{l}n 82 \text { (girls) } \\
\text { Age: mean } 12 \cdot 2 \text { (SD } 0 \cdot 3) \text { years, } \\
18 \text { months } \\
\text { UK }\end{array}$ & $\begin{array}{l}\text { Diets: } \\
\text { (a) } 568 \mathrm{ml} \text { milk/d } \\
\text { (b) Control (usual diet) }\end{array}$ & $\begin{array}{l}\text { Increased milk consumption over } 18 \text { months was not } \\
\text { associated with increased height, weight, LBM and } \\
\text { BF }\end{array}$ & Unadjusted & $\leftrightarrow$ \\
\hline Merrilees et al. $(2000)^{(69)}$ & $\begin{array}{l}n 91 \text { (girls) } \\
\text { Age: } 15-16 \text { years, 2-year intervention } \\
\text { and 1-year follow-up } \\
\text { New Zealand }\end{array}$ & $\begin{array}{l}\text { Diets: } \\
\text { (a) Dairy products (1000 } \mathrm{mg} \mathrm{Ca} / \mathrm{d} \text { ) } \\
\text { (b) Control (usual diet) }\end{array}$ & $\begin{array}{l}\text { There were no differences in height, weight, } \mathrm{BF} \text { and } \\
\text { LBM between the two groups after } 2 \text { years and } 1 \text { - } \\
\text { year follow-up }(P>0.05)\end{array}$ & Unadjusted & $\leftrightarrow$ \\
\hline Volek et al. $(2003)^{(70)}$ & $\begin{array}{l}n 28 \text { (boys) } \\
\text { Age: } 13-17 \text { years, } 3 \text { months } \\
\text { USA }\end{array}$ & $\begin{array}{l}\text { Diets: } \\
\text { (a) RT and } 1 \% \text { milk ( } 3 \text { servings/d) } \\
\text { (b) RT and fruit juice ( } 3 \text { servings/d) }\end{array}$ & $\begin{array}{l}\text { There were no differences in body mass, LBM, fat } \\
\text { mass and \%BF over the } 3 \text { months between the milk } \\
\text { and fruit juice groups }(P>0.05)\end{array}$ & Unadjusted & $\leftrightarrow$ \\
\hline Lappe et al. $(2004)^{(76)}$ & $\begin{array}{l}n 59 \text { (girls) } \\
\text { Age: } 9 \text { years, } 2 \text { years } \\
\text { USA }\end{array}$ & $\begin{array}{l}\text { Diets: } \\
\text { (a) Ca-rich diet }(1500 \mathrm{mg} / \mathrm{d}) \\
\text { (b) Habitual diet }\end{array}$ & $\begin{array}{l}\text { There was no difference in change of height, weight, } \\
\text { BMI, fat mass or LBM between the Ca-rich diet } \\
\text { (mainly from dairy products) and the habitual diet } \\
\text { over } 2 \text { years }\end{array}$ & Unadjusted & $\leftrightarrow$ \\
\hline Du et al. (2004) & $\begin{array}{l}n 757 \text { (girls) } \\
\text { Age: } 10 \text { years, } 2 \text { years } \\
\text { China }\end{array}$ & $\begin{array}{l}\text { Diets: } \\
\text { (a) } 330 \mathrm{ml} \text { milk/school day } \\
\text { (b) } 330 \mathrm{ml} \text { milk and vitamin } \\
\mathrm{D}_{3} / \mathrm{school} \mathrm{day} \\
\text { (c) Control (usual diet) }\end{array}$ & $\begin{array}{l}\text { High milk consumption over the } 2 \text { years increased } \\
\text { body weight }(2.9 \% \text { for milk and } 3.7 \% \text { for milk and } \\
\left.\text { vitamin } D_{3} \text { group; } P<0.0005\right) \text { compared with the } \\
\text { control group }(0.8 \% ; P=0.3)\end{array}$ & Baseline & $\uparrow$ \\
\hline Lau et al. $(2004)^{(72)}$ & $\begin{array}{l}n 344 \text { ( } 189 \text { boys) } \\
\text { Age: } 9-10 \text { years, } 18 \text { months } \\
\text { China }\end{array}$ & $\begin{array}{l}\text { Diets: } \\
\text { (a) Milk powder }(40 \mathrm{~g} / \mathrm{d}) \\
\text { (b) Milk powder }(80 \mathrm{~g} / \mathrm{d}) \\
\text { (c) Control (usual diet) }\end{array}$ & $\begin{array}{l}\text { There was no difference in change of height, weight, } \\
\text { LBM and fat mass between either the } 40 \text { or } 80 \mathrm{~g} \\
\text { milk supplementation and the control }(P>0.05)\end{array}$ & $\begin{array}{l}\text { Sex, Tanner stage, } \\
\text { baseline values, } \\
\text { baseline Ca, protein, } \\
\text { physical activity and } \\
\text { time to follow-up }\end{array}$ & $\leftrightarrow$ \\
\hline Gibbons et al. (2004) $)^{(173)}$ & $\begin{array}{l}n 123 \text { (75 boys) } \\
\text { Age: } 8-10 \text { years, } 12-\text {-month } \\
\text { intervention, } 12-\text { month follow-up } \\
\text { New Zealand }\end{array}$ & $\begin{array}{l}\text { Diets: } \\
\text { (a) Dairy products }(80 \mathrm{mg} \text { milk } \\
\text { powder, } 1200 \mathrm{mg} \mathrm{Ca} / \mathrm{d}) \\
\text { (b) Placebo }(80 \mathrm{mg} \text { powder, } 400 \mathrm{mg} \\
\text { Ca/d) }\end{array}$ & $\begin{array}{l}\text { There was no difference in change of height, weight, } \\
\text { LBM and fat mass between the intervention and the } \\
\text { placebo group }(P>0.05)\end{array}$ & Unadjusted & $\leftrightarrow$ \\
\hline Cheng et al. $(2005)^{(71)}$ & $\begin{array}{l}n 195 \text { (girls) } \\
\text { Age: } 10-12 \text { years, } 2 \text {-year follow-up } \\
\text { Finland }\end{array}$ & $\begin{array}{l}\text { Diets: } \\
\text { (a) Ca }(1000 \mathrm{mg}) \text { and vitamin } \mathrm{D}_{3} \\
\text { (b) Ca }(1000 \mathrm{mg}) \\
\text { (c) Cheese }(1000 \mathrm{mg} \mathrm{Ca}) \\
\text { (d) Placebo } \\
\text { (e) Habitual diet }(>900 \mathrm{mg} \mathrm{Ca})\end{array}$ & $\begin{array}{l}\text { There were no differences in changes in body weight, } \\
\text { fat mass, LBM and height between the groups after } \\
2 \text { years }(P>0.05)\end{array}$ & Unadjusted & $\begin{array}{l}\leftrightarrow(\text { Ca }) \\
\leftrightarrow \text { (Cheese) }\end{array}$ \\
\hline DeJongh et al. (2006) ${ }^{(174)}$ & $\begin{array}{l}n 178 \text { ( } 93 \text { boys) } \\
\text { Age: } 3-5 \text { years, } 1 \text { year } \\
\text { USA }\end{array}$ & $\begin{array}{l}\text { Diets: } \\
\text { (a) Diet and } 1000 \mathrm{mg} \text { supplementary } \\
\text { Ca } \\
\text { (b) Diet and placebo }(0 \mathrm{mg} \mathrm{Ca})\end{array}$ & $\begin{array}{l}\text { There was no difference in changes in fat mass or } \% \\
\mathrm{BF} \text { and dietary } \mathrm{Ca}(r-0.01, P=0.9 \text { and } r-0.05 \text {, } \\
P=0.5) \text { or total (dietary and supplementary) } \mathrm{Ca} \\
\text { intake }(r-0.02, P=0.8 \text { and } r-0.06, P=0.4)\end{array}$ & Unadjusted & $\leftrightarrow$ \\
\hline Albala et al. $(2008)^{(80)}$ & $\begin{array}{l}n 98 \text { ( } 52 \text { boys) } \\
\text { Age: } 8-10 \text { years, } 4 \text { months } \\
\text { China }\end{array}$ & $\begin{array}{l}\text { Diets: } \\
\text { (a) Milk ( } 3 \text { servings/d) and no sugar- } \\
\text { sweetened beverages } \\
\text { (b) Control (usual diet) }\end{array}$ & $\begin{array}{l}\text { There was no difference in change of total fat mass } \\
\text { between the intervention and control groups, yet } \\
\text { LBM remained higher }(P=0.04) \text { following the } \\
\text { intervention }(0.92(\text { SE } 0.10) \mathrm{kg}) \text { than in the control } \\
\text { group }(0.62(\text { SE } 0.11) \mathrm{kg})\end{array}$ & Age, sex & $\leftrightarrow(\mathrm{BF})$ \\
\hline
\end{tabular}




\section{Notrition Research Reviews}

Table 2 Continued

\begin{tabular}{|c|c|c|c|c|c|}
\hline Reference & Details & Intervention & Results and conclusion & Adjustment & Effect \\
\hline $\begin{array}{l}\text { Ghayour-Mobarhan et al. } \\
(2009)^{(86)}\end{array}$ & $\begin{array}{l}n 96 \\
\text { Age: } 12-18 \text { years, } 3 \text { months } \\
\text { Iran }\end{array}$ & $\begin{array}{l}\text { Diets: } \\
\text { (a) } 500 \mathrm{kcal}(2090 \mathrm{~kJ}) / \mathrm{d} \text { deficit and } \\
\text { dairy products }(2 \text { servings } / \mathrm{d}) \\
\text { (b) } 500 \mathrm{kcal}(2090 \mathrm{~kJ}) / \mathrm{d} \text { deficit and } \\
\text { dairy products }(3 \text { servings } / \mathrm{d}) \\
\text { (c) } 500 \mathrm{kcal}(2090 \mathrm{~kJ}) / \mathrm{d} \text { deficit and } \\
\text { dairy products }(4 \text { servings } / \mathrm{d})\end{array}$ & $\begin{array}{l}\text { Increased dairy product consumption over } 3 \text { months } \\
\text { was not associated with augmented BMI, BMI } z \\
\text { score, weight, \%BF and BF mass in overweight and } \\
\text { obese children under an energy-restricted diet }\end{array}$ & Age, sex, ethnicity & $\leftrightarrow$ \\
\hline St-Onge et al. (2009) ${ }^{(82)}$ & $\begin{array}{l}n 45 \text { ( } 9 \text { boys) } \\
\text { Age: } 8-10 \text { years, } 4 \text { months } \\
\text { USA }\end{array}$ & $\begin{array}{l}\text { Diets: } \\
\text { (a) High milk }(4 \times 236 \mathrm{ml} / \mathrm{d}) \\
\text { (b) Low milk }(1 \times 236 \mathrm{ml} / \mathrm{d})\end{array}$ & $\begin{array}{l}\text { There were no differences in change of body weight } \\
\text { or body composition between the high- and low- } \\
\text { milk consumption groups in overweight children } \\
\text { over } 16 \text { weeks }\end{array}$ & Unadjusted & $\leftrightarrow$ \\
\hline Kelishadi et al. (2009) ${ }^{(83)}$ & $\begin{array}{l}n 95 \\
\text { Age: mean 5.6 (sD 0.5) years, 6-month } \\
\text { intervention, 3-year follow-up } \\
\text { (assessed twice yearly) } \\
\text { Iran }\end{array}$ & $\begin{array}{l}\text { Diets: } \\
\text { (a) Isoenergetic dairy-food-rich diet } \\
(>800 \mathrm{mg} \mathrm{Ca} / \mathrm{d}) \\
\text { (b) Energy-restricted diet } \\
\text { (c) Control (no dietary } \\
\text { recommendations) }\end{array}$ & $\begin{array}{l}\text { There were no differences in BMI-SDS, \%BF and WC } \\
\text { between the three groups after the } 6 \text {-month } \\
\text { intervention, yet the high dairy product group had } \\
\text { lower increases in BMI-SDS and WC than the } \\
\text { energy-restricted and control groups over the } \\
\text { follow-up }(P=0.04)\end{array}$ & Unadjusted & $\begin{array}{l}\leftrightarrow \\
\quad \text { (Intervention) } \\
\downarrow \text { (Follow-up) }\end{array}$ \\
\hline Weaver et al. $(2011)^{(90)}$ & $\begin{array}{l}n 42 \text { ( } 17 \text { boys), overweight } \\
\text { Age: } 12-15 \text { years, } 3 \text { weeks } \\
\text { USA }\end{array}$ & $\begin{array}{l}\text { Diets: } \\
\text { Cross-over design } \\
\text { (a) Intervention }(1300 \mathrm{mg} \mathrm{Ca} / \mathrm{d}) \\
\text { (1) } \mathrm{CaCO}_{3}(50 \% \text { children }) \\
\text { (2) Dairy } \mathrm{Ca}(50 \% \text { children }) \\
\text { (b) Control }(650 \mathrm{mg} \text { diet } \mathrm{Ca} / \mathrm{d})\end{array}$ & $\begin{array}{l}\text { There were no differences in changes in body weight } \\
\text { between the control and intervention sessions } \\
\text { (from either } \mathrm{CaCO}_{3} \text { or dairy } \mathrm{Ca} \text { ) in adolescent } \\
\text { overweight boys and girls }(P=0.6)\end{array}$ & Unadjusted & $\leftrightarrow$ \\
\hline Arnberg et al. (2012) & $\begin{array}{l}n 203 \text { ( } 120 \text { boys) } \\
\text { Age: } 12-15 \text { years, } 3 \text { months } \\
\text { Denmark }\end{array}$ & $\begin{array}{l}\text { Diets: } \\
\text { (a) Pre-test control } \\
\text { (b) Water } \\
\text { (c) Casein }(35 \mathrm{~g} \text { protein/l) } \\
\text { (d) Skimmed milk }(1 \mathrm{litre} / \mathrm{d}) \\
\text { (e) Whey }(35 \mathrm{~g} \text { protein/l) }\end{array}$ & $\begin{array}{l}\text { High consumption of skimmed milk, whey and casein } \\
\text { for } 3 \text { months increased BMl-for-age } z \text { scores and } \\
\text { WC compared with pre-test control and water } \\
\text { groups in overweight adolescents }(P<0.05)\end{array}$ & $\begin{array}{l}\text { Age, sex, pubertal } \\
\text { stage }\end{array}$ & $\uparrow$ \\
\hline Larnkjaer et al. (2014) ${ }^{(79)}$ & $\begin{array}{l}n 193 \text { ( } 120 \text { boys) } \\
\text { Age: } 12-15 \text { years, } 3 \text { months } \\
\text { Denmark }\end{array}$ & $\begin{array}{l}\text { Diets } \\
\text { (a) Pre-test control } \\
\text { (b) Water } \\
\text { (c) Casein }(35 \mathrm{~g} \text { protein/l) } \\
\text { (d) Skimmed milk }(1 \text { litre/d) } \\
\text { (e) Whey }(35 \mathrm{~g} \text { protein } / /)\end{array}$ & $\begin{array}{l}\text { High consumption of skimmed milk, whey and casein } \\
\text { for } 3 \text { months increased FMI compared with water } \\
(P<0.05) \text {, whilst all four groups increased LMI } \\
\text { more than the pre-test control group in overweight } \\
\text { adolescents }(P<0.05)\end{array}$ & $\begin{array}{l}\text { Age, sex, pubertal } \\
\text { stage }\end{array}$ & $\uparrow$ \\
\hline Weber et al. $(2017)^{(73)}$ & $\begin{array}{l}n 139 \text { ( } 86 \text { girls) } \\
\text { Age: } 7-10 \text { years, } 36 \text { months } \\
\text { USA }\end{array}$ & $\begin{array}{l}\text { Diets: } \\
\text { (a) Intervention (behavioural } \\
\text { modification and nutritional } \\
\text { education (1500 mg diet Ca/d)) } \\
\text { (b) Control (usual-care group) }\end{array}$ & $\begin{array}{l}\text { High consumption of dietary Ca was associated with } \\
\text { lower increases in } \mathrm{BMI}(\beta-0.0012(95 \% \mathrm{Cl}-0.002, \\
-0.001) ; P=0.007) \text { and } \mathrm{FMl}(\beta-0.001(95 \% \\
\mathrm{Cl}-0.002,-0.001) ; P=0.02) \text { at } 24 \text { months in both } \\
\text { intervention and control groups }\end{array}$ & $\begin{array}{l}\text { Age, sex, African } \\
\text { American ancestry } \\
\text { group }\end{array}$ & $\downarrow$ \\
\hline Lappe et al. $(2017)^{(81)}$ & $\begin{array}{l}n 274 \text { (girls) } \\
\text { Age: } 13-14 \text { years, } 12 \text { months } \\
\text { USA }\end{array}$ & $\begin{array}{l}\text { Diets: } \\
\text { (a) Dairy products }(\geq 1200 \mathrm{mg} \mathrm{Ca} / \mathrm{d} \text { ) } \\
\text { (b) Control (usual diet, } \leq 600 \mathrm{mg} \mathrm{Ca} / \mathrm{d} \text { ) }\end{array}$ & $\begin{array}{l}\text { There were no differences in change of } \mathrm{BF}(P=0.45) \\
\text { or weight gain }(P=0.58) \text { between the groups in } \\
\text { overweight adolescent girls over } 12 \text { months }\end{array}$ & Unadjusted & $\leftrightarrow$ \\
\hline Vogel et al. $(2017)^{(74)}$ & $\begin{array}{l}n 240 \text { ( } 86 \text { boys) } \\
\text { Age: } 8-16 \text { years, } 18 \text { months } \\
\text { USA }\end{array}$ & $\begin{array}{l}\text { Diets: } \\
\text { (a) Dairy products (additional } 3 \\
\text { servings/d) } \\
\text { (b) Control (usual low-dairy food diet) }\end{array}$ & $\begin{array}{l}\text { There were no differences in change of BF gain by } \\
\text { increasing dairy product consumption to } 3 \\
\text { servings/d }(1500 \mathrm{mg} \mathrm{Ca} / \mathrm{d}) \text { compared with } 2 \\
\text { servings/d }(1000 \mathrm{mg} \mathrm{Ca} / \mathrm{d}) \text { independent of weight } \\
\text { status, sex or race over } 18 \text { months }\end{array}$ & $\begin{array}{l}\text { Sex, race, study site, } \\
\text { Tanner stage }\end{array}$ & $\leftrightarrow$ \\
\hline
\end{tabular}

$\% \mathrm{BF}$, percentage body fat; $\leftrightarrow$, null association between exposure (dairy products) and a measure of body fatness; LBM, lean body mass; BF, body fat; RT, resistance training; $\uparrow$, positive association between exposure (dairy products) and a measure of body fatness; SDS, standard deviation score; WC, waist circumference; $\downarrow$, negative association between exposure (dairy products) and a measure of body fatness; FMI, fat mass index; LMI, lean mass index. 
vitamin D or a control group (habitual diet). There were no differences in body height and weight between the three groups over the 24-month study period, yet milk consumption substantially increased height, sitting height and body weight when expressed by mean percentage changes from baseline compared with the control.

\section{Dairy products v. dietary/supplemental calcium}

Although the effect of exclusively supplemental Ca on body composition is out of the scope of the present review, it is worth mentioning the only study that was designed to examine the effects of both dairy products and $\mathrm{Ca}$ supplements (calcium carbonate tablets) on bone mass accrual and body composition, therefore allowing a direct comparison and an important insight into the purported bioactive components of dairy products ${ }^{(71)}$. In this 2 -year randomised trial in 10- to 12-year-old girls, findings indicated no differences in body weight, height, lean tissue and fat mass between the cheese $(1000 \mathrm{mg} / \mathrm{d})$, the supplemental $\mathrm{Ca}(1000 \mathrm{mg} / \mathrm{d})$, the placebo and the reference group (habitual high $\mathrm{Ca}$ intake $>900 \mathrm{mg} / \mathrm{d}$ ). The authors suggested that the lack of differences in body composition could have been masked by the diverse growth pattern in the girls. In concordance with the findings based on bone health studies, Lappe et al. ${ }^{(76)}$ showed that 9-year-old girls in the high Ca diet group (1656 (sD 191) $\mathrm{mg} \mathrm{Ca/d}$ ) compared with the control group (usual diet: 961 (sD 191) $\mathrm{mg} \mathrm{Ca} / \mathrm{d}$ ) gained similar body weight (34 v. 33\%; P>0.05), lean mass (31 v. 31\%; $P>0.05$ ) and fat mass (38v. 33\%; P>0.05) despite the nearly two-fold increase in dairy product consumption in the treatment group over 2 years. Based on a recent meta-analysis of combined results from nine studies including both observational and randomised clinical trials ${ }^{(77)}$, Ca intake (derived from Ca-rich foods, dairy products and $\mathrm{Ca}$ supplements) was inversely related to body weight gain in children and adolescents (mean -0.26 (95\% CI $-0 \cdot 41,-0 \cdot 11) \mathrm{kg} ; P<0 \cdot 001)$.

\section{Differences by type of milk and other dairy products}

Most intervention trials, like observational studies, have examined only milk or total dairy products, with no studies having addressed the effect of 'type' of dairy products on childhood and adolescent obesity. Arnberg et al. ${ }^{(78)}$ conducted a 3-month randomised parallel study (the Milk Components and Metabolic Syndrome (MoMS) study) in overweight subjects aged 12-15 years and showed that adolescents in the skimmed milk (1 litre/d), whey- and casein-based drink (35 g protein/1 per d) supplementation groups increased BMI-for-age $z$ scores compared with the control group (water intake) and pre-test control subgroup (3 months before intervention). However, given that puberty is a period of rapid growth, BMI is not the most representative and adequate index of body composition. Thus, Larnkjaer et $a l .{ }^{(79)}$ in a follow-up analysis of this study demonstrated that milk-based drinks increased both body fat and lean mass. Although milk-based drinks improved body composition by increasing lean mass and maintaining fat mass relative to pre-test control, they had a less favourable effect on body composition than water intake. However, this could be attributable to the replacement of one energy drink for a nonenergy beverage such as water. Replacement of one energy drink for another was examined in a 16-week study, which included an intervention with increasing flavoured milk, whilst almost eliminating sugar-sweetened beverage consumption by delivering milk beverages to the homes of overweight and obese 8- to 10-year-old children ${ }^{(80)}$. Although no differences in percentage of body fat were observed, milk consumption increased the accretion of lean body mass compared with the control (usual diet). Of all the randomised intervention studies reviewed, the recent study by Lappe et $a l .{ }^{(81)}$ is the first study to report the effects of dairy food on body weight and fat in adolescents. They enrolled 13- to 14-year-old girls with BMI between the 50th to 98th percentiles and with habitual low Ca intake $(<600 \mathrm{mg} / \mathrm{d})$ and assigned them to either the intervention dairy food group (reduced-fat milk and yoghurt, $\geq 1200 \mathrm{mg} \mathrm{Ca} / \mathrm{d}$ ) or the control group (usual diet) for 12 months. There were no differences in weight and fat gain between the dairy food and control groups. In an explanatory analysis, they found that the effect of reduced-fat milk did not differ from yoghurt on change in percentage of body fat or weight, yet due to the nature of the intervention incorporating both dairy products, the effect of each type of dairy product remains to be explored.

Interventions aimed to manage childhood overweight and obesity, which included advice on different milk and other dairy products

Two studies included healthy eating counselling as part of their weight management intervention ${ }^{(82,83)}$. Findings from a 16-week randomised parallel trial in 8- to 9-year-old overweight children, indicated that high milk $(4 \times 236 \mathrm{ml} / \mathrm{d})$ compared with low milk $(1 \times 236 \mathrm{ml} / \mathrm{d})$ consumption tended to decrease visceral adipose tissue (-0.18 (SEM 0.08) v. -0.11 (SЕM 0.05) litres; $P>0.05)$, despite the fact that there was no significant change in body weight or body composition ${ }^{(82)}$. As authors suggested, a larger sample size and a longer duration might have been needed to adequately examine and detect body composition changes between the milk groups. Furthermore, a randomised controlled trial in 120 obese and prepubescent children examined the effect of a dairy product-rich diet on long-term weight management ${ }^{(83)}$. The children were randomly assigned to a dairy product-rich diet group $(>800 \mathrm{mgCa} / \mathrm{d}$, without any energy restriction), energy-restricted diet or control group and all of them had six healthy lifestyle family sessions once per month during the 6-month intervention. BMI standard deviation scores and waist circumference were decreased significantly in all groups after the 6 months. A follow-up was done twice yearly for 3 years and a significant increase was observed in BMI and waist circumference given the period of rapid growth. However, the increase was significantly lower in the dairy product group compared with the other two groups suggesting that in addition to lifestyle modifications, a dairy food-rich diet could be a potent strategy for weight management in young overweight children.

Similarly, a recent 38-month study in 7- to 10-year-old children ${ }^{(73)}$ included a behavioural modification and nutritional 
education intervention to gradually increase dietary Ca intake to $1500 \mathrm{mg} / \mathrm{d}$ compared with the usual-care group (a single $45 \mathrm{~min}$ nutrition session). Results showed an increase in Ca intake in the intervention group and an inverse association between dietary $\mathrm{Ca}$ intake and gain in BMI and fat mass irrespective of treatment group.

Although several studies have examined the effect of milk or dairy product consumption on alterations in body weight and composition under energy restriction in adults ${ }^{(84,85)}$, there is only one study which explored the relationship between dairy product consumption and BMI or fat mass in overweight and obese children during energy restriction ${ }^{(86)}$. In this 12-week study, 120 overweight and obese children on an energyrestricted regimen $(500 \mathrm{kcal} / \mathrm{d}(2090 \mathrm{~kJ} / \mathrm{d})$ below requirement) were assigned to two, three or four servings of dairy products/d. There were significant reductions in BMI, body weight and body fat, yet these reductions were due to the energy deficit and independent of the effect of increasing dairy product consumption.

\section{Discussion of intervention studies}

Examining Table 2, many aspects of the study methodology used in the included studies differed considerably, notably the length of the intervention (ranging from 3 months to 2 years) and the number of participants (for example, twenty-eight to 757), with half of the studies using dairy products and the other half milk consumption as part of their intervention. Data from the majority of the studies reviewed show that there is a neutral effect of dairy product ( $n$ 10) and milk $(n 9)$ consumption on body weight and body composition in children and adolescents. More specifically, all the studies that examined the impact of a dairy food-rich diet relative to habitual diet on indicators of adiposity showed neutral effect and three studies ${ }^{(75,78,79)}$ that used milk consumption as the intervention showed an increase in body weight. However, as pointed out in the description of those studies, the increase in body weight was accompanied by an increase in lean mass ${ }^{(78,79)}$ or overall growth ${ }^{(75)}$. Specifically, in the study by Du et al. ${ }^{(75)}$, as the largest school-milk intervention trial, the 757 included girls were healthy but on a persistently low-Ca diet and had a high prevalence of vitamin D deficiency ${ }^{(87)}$, thus representing a population that is not comparable with most of the intervention studies examined.

It is also noteworthy that there are no studies with body composition or any other indicators of obesity that have included intervention with both regular or reduced-fat milk or other type of dairy products, thereby not allowing a direct comparison. The processing of dairy foods often involves removal of whey protein from cheese, or addition of ingredients such as sugar in flavoured milk, yoghurt and ice-creams ${ }^{(88)}$. It can also lead to a number of alterations or biochemical changes in milk constituents, macronutrients and bioactive factors through such as insulin-like growth factor-1 (IGF-1) ${ }^{(89)}$. Thus, using total dairy product consumption might not be a suitable variable to elucidate the underlying impact of milk and other type of dairy products on adiposity indicators. Among the randomised controlled trials reviewed that included total dairy products, most included milk, cheese and yoghurt with a few studies including additionally dairy desserts ${ }^{(69)}$ or any curd products ${ }^{(83)}$. However, there were no reports in the percentage of milk or other dairy products contribution to the total dairy product consumption, which does not allow examination of any differential effects. Thus, disaggregation of dairy products, such as reduced-fat compared with full-fat milk, fermented products such as yoghurt and cheese and in general those that are encouraged by the dietary guidelines as opposed to those that should be consumed sporadically (i.e. ice-cream, milkshakes), is essential in the analysis of children and adolescent obesity.

Dairy food serving sizes were adequately defined in most of the intervention studies with feasible quantification of milk and total dairy product consumption with the observed outcomes. However, variation in the definition of serving size/portions and high, low or habitual milk or dairy product consumption among the studies is apparent, which makes it very difficult, if not inappropriate, to compare results across studies conducted in different location and populations. For instance, while in Finland a habitual diet contains approximately $900 \mathrm{mg} \mathrm{Ca} / \mathrm{d}^{(71)}$, in the USA population this is reported to contain between 600 and $700 \mathrm{mg} \mathrm{Ca} / \mathrm{d}^{(74,81,90)}$. There were also variations in the way the outcome variable is reported within studies, with most studies reporting body weight, BMI, lean body mass, percentage body fat while very few reported BMI $z$ score, waist circumference or waist:height ratio, which have been suggested as more appropriate for children and adolescents and important early markers for the development of chronic diseases ${ }^{(91,92)}$.

The majority of the included studies were predominately conducted in girls $(n 7)$ and in school-aged children and adolescents. There were no differences in the outcome variables related to sex comparing the studies that included only girls and those that included both sexes ( $n$ 12). However, sex was adjusted in seven out of twelve studies and rate of growth (pubertal or Tanner stage) adjusted in only four ${ }^{(72,74,78,79)}$ out of eighteen studies conducted in school-aged children and adolescents (age 8-18 years).

It is important to recognise that many of the intervention studies (thirteen out of twenty) included had a nonintervention control group, reported as usual or habitual diet often low in milk or dairy products, as the comparator to increased milk and total dairy food intervention group. Although this information allows separating the effects of treatment group on measures of adiposity, it does not provide insight on whether the effects observed are attributable to the increased milk or dairy product consumption per se, or to the concomitant manipulation of other food groups. Only one study utilised an isoenergetic replacement food such as fruit juice $^{(70)}$ as a comparator to milk and another study increased the consumption of milk by decreasing the consumption of sugar-sweetened beverages ${ }^{(80)}$, therefore separating the effect of milk. Both of those studies showed a neutral effect of increased milk consumption compared with fruit juice or usual diet on lean and fat mass ${ }^{(70,80)}$. Future studies should try to include both positive (i.e. isoenergetic food or beverages) and negative comparators (i.e. water or no milk group) to increase the ability to draw robust conclusions with regard to the treatment effect. 
Although intervention studies are highly diverse considering the duration, location or sample size (Table 2), there are no clear patterns or trends identified between the interventions of milk or other dairy products that influence body weight and indicators of adiposity positively, neutrally or negatively. Additionally, half of the intervention studies were funded by the dairy or food industry and results showed that the source of funding did not affect the results.

Taken together, data from the majority of the intervention studies reviewed show that there is a neutral effect of dairy product and mainly milk consumption compared with the habitual diet on body weight and body composition in children and adolescents. Inclusion of milk and other dairy products as part of an energy-restricted diet did not enhance, but neither did it adversely affect, BMI or weight loss. However, given the limited data available from studies conducted under conditions of energy restriction, no conclusions can be drawn.

\section{Plausible mechanisms underlying the effect of dairy} components on body-weight regulation

Given the inconsistencies among the studies reviewed, there is a great need to understand the mechanisms by which dairy products affect energy balance and consequently body weight or composition. As reviewed elsewhere ${ }^{(93-95)}$, a number of different plausible mechanisms have been suggested, with the most frequently cited mechanism relating to the effects of intracellular ionised $\mathrm{Ca}$ on adipocyte metabolism ${ }^{(96,97)}$. According to this theory, an increase in dietary Ca via its influence on circulating calcitropic hormones (suppression of the 1,25-hydroxyvitamin D and parathyroid hormone concentrations) reduces the concentration of intracellular ionised $\mathrm{Ca}$ in human adipocytes. The resultant decrease in ionised $\mathrm{Ca}$ stimulates lipolysis, inhibits de novo lipogenesis and increases fat oxidation ${ }^{(98,99)}$. Gonzalez et al. ${ }^{(100)}$ showed in a metaanalysis that an increase in dietary Ca by $800 \mathrm{mg} / \mathrm{d}$ predicted an $11 \%$ increase in fat oxidation with more pronounced effects when habitual chronic Ca intake was low ( $<700 \mathrm{mg} / \mathrm{d})$. However, the hypothesis of reduced adipogenesis through dietary $\mathrm{Ca}$ has been refuted by some human studies ${ }^{(101,102)}$. There is also some evidence that $\mathrm{Ca}$ in the form of dairy foods exerts greater effect than Ca supplements ${ }^{(103)}$. This could be attributable to the synergistic actions of $\mathrm{Ca}$ with several bioactive compounds present in dairy products such as branched-chain amino acids, i.e. leucine ${ }^{(104)}$. Peptides in whey protein inhibit angiotensin-converting enzyme, which suppresses angiotensin II hormone production and consequently stimulation of adipocyte lipogenesis, resulting in reduction of fat accumulation ${ }^{(105,106)}$. Fatty acids in dairy products such as medium-chain fatty acids and conjugated linoleic acid have also been shown to reduce lipogenesis and increase fat oxidation in the adipocyte via suppressing the expression of pro-adipogenic cell signals including PPAR $\gamma^{(107-110)}$

Additionally, dietary Ca may exert the anti-obesity effect mediated by increased faecal fat excretion ${ }^{(111,112)}$. Specifically, $\mathrm{Ca}$ interferes with fat absorption in the gastrointestinal tract by binding fatty acids to form insoluble Ca soaps or by creating precipitates with phosphate and bile acids, which decreases the digestible energy from the diet and contributes to a negative energy balance ${ }^{(113)}$. Christensen et al. ${ }^{(114)}$ showed in a metaanalysis of fifteen studies, including one study in children ${ }^{(115)}$, that increased $\mathrm{Ca}$ intake from both supplements and dairy products of $1241 \mathrm{mg} / \mathrm{d}$ increased faecal fat excretion by $5.2 \mathrm{~g} / \mathrm{d}$. However, limited studies have examined these mechanisms in children and adolescents ${ }^{(81,90)}$ and results do not support any effect of dietary $\mathrm{Ca}$ or dairy products on energy, fat or $\mathrm{N}$ balances in overweight adolescents when energy intake and physical activity are controlled. These results were independent of the Ca source (dairy foods or calcium carbonate supplements) or when stratified by the baseline BMI percentile. As the authors stated, the contrasting results between adolescents and adults regarding faecal fat excretion could be attributable to the higher faecal $\mathrm{Ca}$ in adults compared with adolescents who had similar $\mathrm{Ca}$ intake ${ }^{(90)}$. Furthermore, in addition to sex-related differences (higher visceral fat deposition ${ }^{(116)}$ and thermogenic oxidation $^{(90)}$ in boys), several dynamic metabolic changes occur in a period of rapid growth and puberty that could further complicate the mechanistic pathways ${ }^{(117)}$.

Another proposed mechanism refers to the $\mathrm{Ca}$ appetite concept, which according to Tordoff ${ }^{(118)}$, dietary Ca depletion triggers the appetite for Ca-rich foods. There are some plausible mechanisms, which rely on the identification of certain genes responsible for taste recognition ${ }^{(119)}$ and an increase in the fasting anorexigenic hormone leptin ${ }^{(120)}$ or postprandial levels of anorexigenic glucose-dependent insulinotropic peptide and glucagon-like peptide after ingestion of $\mathrm{Ca}^{(121)}$, yet with inconsistent results ${ }^{(122,123)}$. Specific components of dairy foods and mainly whey and casein proteins have been associated with increased satiety ${ }^{(124)}$ through delayed gastric emptying ${ }^{(125)}$, and regulation of the concentration of plasma amino $\operatorname{acid}^{(126)}$ and gastrointestinal hormones such as cholecystokinin $^{(127)}$, peptide $\mathrm{YY}^{(128)}$ and gastrin ${ }^{(129)}$. However, it remains unknown whether the satiating effect is due to $\mathrm{Ca}$ or the dairy matrix ${ }^{(130)}$, with inconsistent results in the limited studies conducted in children and adolescents, as discussed later.

Certain dairy products such as yoghurt might exert the antiobesity effect mediated by manipulation of the composition and metabolic activity of gut microbiota ${ }^{(131,132)}$. The composition of the intestinal microbiota differs between normal-weight and obese/overweight children ${ }^{(133,134)}$ and there is evidence that early differences in gut microbiota composition in children could predict overweight ${ }^{(135)}$. Given that fermented dairy products are a source of probiotics, some plausible mechanisms, which are still poorly understood, suggest an interaction of probiotics with indigenous bacteria in the gastrointestinal tract that might influence the metabolic pathways involved in lipid metabolism $^{(136)}$. Although the few studies conducted in that area showed beneficial effects of probiotics on weight management in children $^{(137,138)}$, further research is clearly needed.

A few observational and intervention studies showed a positive association between milk and other dairy products $^{(41,43,75,78,79)}$ and particularly dairy proteins ${ }^{(139,140)}$ with weight gain. Putative mechanisms explaining increased weight gain include the stimulation of IGF-1 ${ }^{(141-143)}$, which has a 
negative impact on preadipocyte differentiation and multiplication $^{(144,145)}$. However, there are conflicting results with regards to the relationship between IGF-1 concentration and BMI in children ${ }^{(146-148)}$.

In addition, milk proteins have also been shown to stimulate insulin secretion ${ }^{(149-151)}$, which is another growth hormone due to its binding to IGF-1 receptors, thus promoting cell replication in connective and musculoskeletal tissue ${ }^{(152)}$. Further research is needed in order to elucidate the putative mechanisms underlying the impact of dairy components on body weight regulation.

\section{Evidence from intervention studies of the effect of dairy product intake on appetite and energy intake regulation}

Given that obesity is characterised by an imbalance between energy intake and expenditure, understanding the factors or dietary components that could regulate appetite and energy intake has been a substantial focus in recent years. Although several studies have examined the effect of milk and other dairy product consumption as whole foods on appetite and subsequent meal energy intake in adults ${ }^{(153-156)}$, there is a limited number of studies conducted in children ${ }^{(157-161)}$. Brindal et $a{ }^{(157)}$ showed that there was no difference in subsequent appetite or energy intake at the ad libitum lunch $3 \mathrm{~h}$ after the consumption of a full milk beverage compared with isoenergetic half milk/glucose and glucose beverages in 10- to 12 -year-old children. In contrast, Mehrabani et al. ${ }^{(158)}$ recently showed that 10- to 12-year-old obese boys who consumed a fixed content breakfast with low-fat milk for two consecutive days had lower subjective appetite ratings and subsequent energy intake at lunch $5 \mathrm{~h}$ after, compared with apple juice and water $(1010 \mathrm{kcal}(4226 \mathrm{~kJ}), 1059 \mathrm{kcal}(4431 \mathrm{~kJ})$ and $1236 \mathrm{kcal}$ $(5171 \mathrm{~kJ})$, respectively; $P<0 \cdot 001)$. Furthermore, Green et al. ${ }^{(161)}$ showed that acute mid-morning milk consumption as a snack reduced ad libitum energy intake compared with an isoenergetic and isovolumetric serving of fruit juice in adolescent boys. Differences in subjects' characteristics (obese boys $v$. normal-weight boys and girls) and time interval between breakfast or snack and the ad libitum lunch could explain the discrepancy in results between the studies. Furthermore, Mehrabani et $a l .{ }^{(158)}$ provided one serving of fruit between the breakfast and lunch which could have assisted in prolonging the feelings of satisfaction up to $5 \mathrm{~h}$, whilst Brindal et al. ${ }^{(157)}$ used an interval of $3 \mathrm{~h}$ where appetite ratings have returned to baseline values. Despite the modest decrease in energy intake by $50 \mathrm{kcal}(209 \mathrm{~kJ})$ between milk and apple juice, the authors suggested it could help with energy control and maintaining a healthy weight in the longer term.

\section{Free-living setting outcomes}

The majority of the studies have investigated appetite and energy intake as the primary endpoints within a laboratory setting but some of the studies, which included assessment of energy intake as part of body weight measurements, could shed some light on the effect of dairy foods on energy intake in a free-living environment. For instance, Lappe et al. ${ }^{(76)}$ showed that girls consuming a Ca-rich diet were not ingesting more energy relative to those on their habitual diet and Albala et $a l .{ }^{(80)}$ reported decreased energy intake by the concurrent replacement of sugar-sweetened beverages with milk consumption compared with control $(-91 v .9 .7 \mathrm{kcal} / \mathrm{d}(-381 v$. $41 \mathrm{~kJ} / \mathrm{d}) ; \quad P=0.03)$. Similarly, Andersen et al. ${ }^{(162)}$ recently revisited the MoMS intervention study, investigating the effects of increased water or milk-based drinks on total energy intake and dietary patterns in overweight adolescents. Although water intake reduced $(-236 \mathrm{kcal} / \mathrm{d}(-987 \mathrm{~kJ} / \mathrm{d})$ while milk-based drinks did not alter total energy intake during the 12-week intervention compared with the background diet (baseline), both water and milk-based drinks had a favourable effect on the diet by decreasing the consumption of convenience foods, including sugar-sweetened beverages. This is particularly important given that there were no other restrictions in the diet and the milk-based drinks were added as extra intake, implying a compensatory effect of those on energy balance and reflecting positive dietary changes in usual life and free-living behaviour. Finally Green et $a l^{(161)}$ recently showed no statistically significant differences between chronic ( $28 \mathrm{~d}$ ) milk and fruit juice consumption as a mid-morning snack on change in total daily energy intake. However, with the group consuming milk as a mid-morning snack, total daily energy intake declined over the $28 \mathrm{~d}(P=0.013)$; no such change was observed in the group consuming fruit juice.

\section{Effect of type of milk or dairy product on satiety and energy} intake

Considering the impact of the type of dairy foods with regard to the fat content on satiation and energy intake, Kling et al. ${ }^{(159)}$ recently showed that there was a compensatory effect of full-fat relative to low-fat milk consumption when served with lunch on preschoolers' food intake, although there were no differences in total meal energy intake (lunch + milk). However, there was a sex effect; lunch intake was reduced by 43 (SEM 8) kcal (180 (SEM $33) \mathrm{kJ})(P=0 \cdot 001)$ after full-fat milk without altering total meal energy intake for boys, whereas in girls there was no reduction in lunch intake, which increased total meal energy intake by 24 (sEm 10) kcal (100 (sem 42) kJ) $(P=0 \cdot 03)$. However, this was an acute study and it remains unknown whether energy compensation persists over the whole day or in intakes over the long term. There is one study which examined the effect of replacing regular-fat with reduced- or low-fat dairy products on dietary intakes and health outcomes ${ }^{(163)}$. In this 24 -week cluster randomised controlled trial, parents and their 4- to 13-year-old children were randomly assigned to behavioural nutrition education to change to reduced-fat dairy products (intervention group) or reduce screen time (control group). The results indicated that there was a $74 \%$ decrease in regular-fat dairy product intake in the intervention group, which led to a reduction of 3.3 percentage points in saturated fat compared with the control group at week 24 . However, there was no difference in total energy intake $(-195(95 \% \mathrm{CI}-772,383) \mathrm{kJ}$; $P=0.504)$ or BMI $z$ score and waist circumference between the 
two groups. The authors in a secondary analysis of this trial tried to address whether there was compensation or energy adjustment by incorporating other foods in the diet when lowerenergy-dense dairy products were introduced ${ }^{(164)}$. The results showed that replacing regular- with reduced-fat dairy foods did not adversely have an impact on children's overall food intake by revealing no differences in food group contribution to energy intake between the intervention and the control group at week 24 . The foods that contained excess fat, added sugar and/ or salt had the largest contribution to children's total energy intake (27\%) and saturated fat intake (33\%), highlighting that reduction of energy-dense foods is necessary to achieve better control of saturated fat and total energy intake.

In general, inclusion of any dairy products into weightmaintenance diets did not lead to a higher overall energy intake, implying a partial compensatory effect of milk on energy balance. Further, adequately designed studies are needed to examine if habitual consumption of milk and other dairy products make an impact on appetite regulation and consequently energy intake in children and adolescents.

\section{Overall conclusions}

This critical and comprehensive review of evidence based on ninety-four studies of different study designs found that milk and other dairy products are consistently not associated, or inversely associated, with body fatness in children relative to low or no dairy product consumption. More specifically, results from observational studies presented as both unadjusted, and as adjusted, for energy intakes indicate that adjustment for energy intake tended to change negative associations to null or neutral. Our findings are based on forty-three cross-sectional and thirtyone longitudinal studies. Only six studies of the seventy-four observational studies reviewed found any positive association between any component of milk or other dairy products and body fatness in children, and for two of these five studies the exposure was milk protein. The majority of the twenty intervention studies showed no differences in body weight and body composition between children and adolescents who increased dairy food and mainly milk consumption and those who maintained their habitual diet. Only one study included energy intake restriction and increased dairy product consumption; neither BMI nor weight loss was enhanced or adversely affected, yet no firm conclusions can be drawn due to limited data available under energy restriction.

We did endeavour to assess whether the relationship was different by type of milk and milk product. Although some studies did report differences, we consistently found that the type of product did not change the overall direction of travel for both observational and intervention studies. We found that there appeared to be very little difference in the results between milks of differing fat content, regardless of study design.

We also endeavoured to assess whether the relationship was different by age of the child. Most studies were conducted in 8- to 12-year-olds, but only a few studies were conducted in preschool children. The relationship between milk and other dairy products, and body fatness in children, did not appear to change during childhood except in the preschool years. Due to the limited data available, and the inconsistency of the results, it is not possible to make any inference about the relationship between milk and other dairy products with obesity and indicators of adiposity, and age of the child. However, we do suggest that further research is warranted on this topic in children $<5$ years of age.

Milk and dairy foods are nutrient rich and make a significant contribution to $\mathrm{Ca}$, iodine, riboflavin, vitamin $\mathrm{B}_{12}, \mathrm{~K}$ and vitamin $\mathrm{A}$ intakes in children. On this basis, we conclude that there is limited and no definitive evidence to support a concern to limit the consumption of milk and other dairy products by children on the grounds that they may promote obesity. Furthermore, the existing evidence shows that there is no accepted underlying mechanistic rationale to support the hypothesis that milk and other dairy products promote excess weight gain, or increase appetite.

Further research is needed to better understand the role of different milks and different dairy foods in childhood obesity. The new and emerging range of products (including plantbased alternatives) being used as dairy milk substitutes has yet to be evaluated in scientific studies.

\section{Acknowledgements}

A funding contribution and information on the nutrient composition and consumption trends of dairy products were provided by The Dairy Council (http://www.milk.co.uk/).

A. D. drafted the manuscript. All authors contributed to, and approved, the final version of the manuscript.

The authors have no relevant conflict of interests to declare.

\section{Supplementary material}

The supplementary material for this article can be found at https://doi.org/10.1017/S0954422418000227

\section{References}

1. World Health Organization (2016) Commission on Ending Childhood Obesity. www.who.int/end-childhood-obesity/ en (accessed October 2018).

2. World Health Organization (2016) Obesity and overweight: fact sheet (updated). http://www.who.int/news-room/factsheets/detail/obesity-and-overweight (accessed October 2018).

3. Monteiro CA, Conde WL, Lu B, et al. (2004) Obesity and inequities in health in the developing world. Int J Obes $\mathbf{2 8}$, 1181-1186.

4. Ebbeling C, Pawlak D \& Ludwig D (2002) Childhood obesity: public-health crisis, common sense cure. Lancet 360, 473-482.

5. Whitaker RC, Wright JA, Pepe MS, et al. (1997) Predicting obesity in young adulthood from childhood and parental obesity. New Engl J Med 337, 869-873.

6. Seidell JC \& Halberstadt J (2015) The global burden of obesity and the challenges of prevention. Ann Nutr Metab 66, Suppl. 2, 7-12. 
7. Change4Life (2017) Change4Life. www.nhs.uk/Change4Life/Pages/change-for-life.aspx (accessed November 2017).

8. Stanford FC, Tauqeer Z \& Kyle TK (2018) Media and its influence on obesity. Curr Obes Rep 7, 186-192.

9. Buttriss JL (2016) The Eatwell Guide refreshed. Nutr Bull 41, 135-141.

10. Change4Life (2014) Swap while you shop: new campaign launched to get families making healthy swaps in January. https://www.gov.uk/government/news/swap-while-youshop-new-campaign-launched-to-get-families-makinghealthy-swaps-in-january (accessed June 2018).

11. NHS (2018) Eat Well: dairy and alternatives in your diet. https://www.nhs.uk/live-well/eat-well/milk-and-dairynutrition/ (accessed June 2018).

12. Public Health England (2018) Closed consultation: UK Nutrient Profiling Model 2018 review. https://www.gov.uk/ government/consultations/consultation-on-the-uk-nutrientprofiling-model-2018-review (accessed June 2018).

13. Garrow J (1979) Weight penalties. Br Med J 2, 1171-1172.

14. European Commission (2017) Milk and milk products. https://ec.europa.eu/food/animals/animalproducts/milk_ en (accessed August 2017).

15. United States Department of Agriculture (2015) 2015-2020 Dietary Guidelines for Americans: 8th edition. https:// health.gov/dietaryguidelines/2015/guidelines/ (accessed October 2018).

16. EUR-Lex (2017) Europa EU Law and Publications Regulation (EC) No 178/2002. http://eur-lex.europa.eu/legalcontent/EN/TXT/?uri=CELEX:32002R0178 (accessed August 2017).

17. Finglas PM, Roe MA, Pinchen HM, et al. (2015) McCance and Widdowson's The Composition of Foods: Seventh Summary Edition. Cambridge: Royal Society of Chemistry.

18. National Research Council (US) Committee on Technological Options to Improve the Nutritional Attributes of Animal Products (1988) Designing Foods: Animal Product Options in the Marketplace. Factors Affecting the Composition of Milk from Dairy Cows. Washington, DC: National Academies Press. https://www.ncbi.nlm.nih.gov/books/ NBK218193/ (accessed October 2018).

19. Auestad N, Hurley JS, Fulgoni VL III, et al. (2015) Contribution of food groups to energy and nutrient intakes in five developed countries. Nutrients 7, 4593-4618.

20. World Health Organization (2018) Global and regional food consumption patterns and trends. http://www.who. int/nutrition/topics/3_foodconsumption/en/index $4 . h t m l$ (accesssed June 2018).

21. Global Nutrition and Policy Consortium (2014) Home of the Global Dietary Database. Tufts Friedman School of Nutrition Science and Policy. https://www.globaldietarydataba se.org/ (accessed June 2018).

22. Louie JCY, Flood VM, Hector DJ, et al. (2011) Dairy consumption and overweight and obesity: a systematic review of prospective cohort studies. Obes Rev 12, 582592.

23. Dror DK \&Allen LH (2013) Dairy product intake in children and adolescents in developed countries: trends, nutritional contribution, and a review of association with health outcomes. Nutr Rev 72, 68-81.

24. Dror DK (2014) Dairy consumption and pre-school, schoolage and adolescent obesity in developed countries: a systematic review and meta-analysis. Obes Rev 15, 516-527.

25. Lu L, Xun P, Wan Y, et al. (2016) Long-term association between dairy consumption and risk of childhood obesity: a systematic review and meta-analysis of prospective cohort studies. Eur J Clin Nutr 70, 414-423.

26. Wang W, Wu Y \& Zhang D (2016) Association of dairy products consumption with risk of obesity in children and adults: a meta-analysis of mainly cross-sectional studies. Ann Epidemiol 26, 870-882.

27. Kouvelioti R, Josse A \& Klentrou P (2017) The effects of dairy consumption on body composition and bone properties in youth: a systematic review. Curr Dev Nutr 1, e001214.

28. Møller MH, Ioannidis JPA \& Darmon M (2018) Are systematic reviews and meta-analyses still useful research? We are not sure. Intensive Care Med 44, 518-520.

29. Nezami M, Segovia-Siapco G, Beeson W, et al. (2016) Associations between consumption of dairy foods and anthropometric indicators of health in adolescents. Nutrients $\mathbf{8}, \mathrm{E} 427$.

30. Wiley A (2010) Dairy and milk consumption and child growth: is BMI involved? An analysis of NHANES 19992004. Am J Hum Biol 22, 517-525.

31. Rangan AM, Flood VL, Denyer G, et al. (2012) The effect of dairy consumption on blood pressure in mid-childhood: CAPS cohort study. Eur J Clin Nutr 66, 652-657.

32. Garden FL, Marks GB, Almqvist C, et al. (2011) Infant and early childhood dietary predictors of overweight at age 8 years in the CAPS population. Eur J Clin Nutr 65, 454-462.

33. Phillips SM, Bandini LG, Cyr H, et al. (2003) Dairy food consumption and body weight and fatness studied longitudinally over the adolescent period. IntJObes 27, 1106-1113.

34. Fayet-Moore F (2015) Effect of flavored milk vs plain milk on total milk intake and nutrient provision in children. Nutr Rev 74, 1-17.

35. Noel S, Ness AR, Northstone K, et al. (2013) Associations between flavored milk consumption and changes in weight and body composition over time: differences among normal and overweight children. Eur J Clin Nutr 67, 295-300.

36. Vanselow MS, Pereira MA, Neumark-Sztainer D, et al. (2009) Adolescent beverage habits and changes in weight over time: findings from Project EAT. Am J Clin Nutr 90, 1489-1495.

37. Kratz M, Baars T \& Guyenet S (2013) The relationship between high-fat dairy consumption and obesity, cardiovascular, and metabolic disease. Eur J Nutr 52, 1-24.

38. Noel S, Ness AR, Northstone K, et al. (2011) Milk intakes are not associated with percent body fat in children from ages 10 to 13 years. $J$ Nutr 141, 2035-2041.

39. Huh SY, Rifas-Shiman SL, Rich-Edwards JW, et al. (2010) Prospective association between milk intake and adiposity in preschool-aged children. J Am Diet Assoc 110, 563-570.

40. Scharf RJ, Demmer RT \& DeBoer MD (2013) Longitudinal evaluation of milk type consumed and weight status in preschoolers. Arch Dis Child 98, 335-340.

41. Berkey C, Rockett H, Willett W, et al. (2005) Milk, dairy fat, dietary calcium, and weight gain. Arch Pediatr Adolesc Med 159, 543-550.

42. Bigornia SJ, LaValley MP, Moore LL, et al. (2014) Dairy intakes at age 10 years do not adversely affect risk of excess adiposity at 13 years. J Nutr 144, 1081-1090.

43. Dubois L, Diasparra M, Bogl L, et al. (2016) Dietary intake at 9 years and subsequent body mass index in adolescent boys and girls: a study of monozygotic twin pairs. Twin Res Hum Genet 19, 47-59.

44. Gidding SS, Dennison BA, Birch LL, et al. (2006) Dietary recommendations for children and adolescents: a guide for practitioners. Pediatrics 117, 544-559. 
45. Carruth BR \& Skinner JD (2001) The role of dietary calcium and other nutrients in moderating body fat in preschool children. Int J Obes Relat Metab Disord 25, 559-566.

46. Skinner JD, Bounds W, Carruth BR, et al. (2003) Longitudinal calcium intake is negatively related to children's body fat indexes. J Am Diet Assoc 103, 1626-1631.

47. Dixon LB, Pellizzon MA, Jawad AF, et al. (2005) Calcium and dairy intake and measures of obesity in hyper- and normocholesterolemic children. Obesity Res 13, 1727-1738.

48. Fisher J, Mitchell D, Smiciklas-Wright H, et al. (2004) Meeting calcium recommendations during middle childhood reflects mother-daughter beverage choices and predicts bone mineral status. Am J Clin Nutr 79, 698-706.

49. Barr S (2007) Calcium and body fat in peripubertal girls: cross-sectional and longitudinal observations. Obesity 15 $1302-1310$.

50. Rockell JEP, Williams SM, Taylor RW, et al. (2004) Twoyear changes in bone and body composition in young children with a history of prolonged milk avoidance. Osteoporos Int 16, 1016-1023.

51. Striegel-Moore RH, Thompson D, Affenito SG, et al. (2006) Correlates of beverage intake in adolescent girls: The National Heart, Lung, and Blood Institute Growth and Health Study. J Pediatr 148, 183-187.

52. Wang Y (2002) Is obesity associated with early sexual maturation? A comparison of the association in American boys versus girls. Pediatrics 110, 903-910.

53. Hasnain SR, Singer MR, Bradlee ML, et al. (2014) Beverage intake in early childhood and change in body fat from preschool to adolescence. Child Obes 10, 42-49.

54. DeBoer MD, Agard HE \& Scharf RJ (2014) Milk intake, height and body mass index in preschool children. Arch Dis Childhood 100, 460-465.

55. Moore LL, Singer MR, Qureshi MM, et al. (2008) Dairy intake and anthropometric measures of body fat among children and adolescents in NHANES. J Am Coll Nutr 27, 702-710.

56. Charney M (2010) Review of bioactive components in milk and dairy products. J Agric Food Inf 11, 358-359.

57. Liu S, Choi HK, Ford E, et al. (2006) A prospective study of dairy intake and the risk of type 2 diabetes in women. Diabetes Care 29, 1579-1584.

58. Margolis KL, Wei F, de Boer IH, et al. (2011) A diet high in low-fat dairy products lowers diabetes risk in postmenopausal women. J Nutr 141, 1969-1974.

59. Sempos C (1992) Invited commentary: some limitations of semi quantitative food frequency questionnaires. Am J Epidemiol 135, 1127-1132.

60. Salvini S, Hunter DJ, Sampson L, et al. (1989) Food-based validation of a dietary questionnaire: the effects of week-toweek variation in food consumption. Int J Epidemiol 18, 858-867.

61. Huang TT, Roberts SB, Howarth NC, et al. (2005) Effect of screening out implausible energy intake reports on relationships between diet and BMI. Obes Rev 13, 1205-1217.

62. Bandini LG, Must A, Cyr $\mathrm{H}$, et al. (2003) Longitudinal changes in the accuracy of reported energy intake in girls 10-15 y of age. Am J Clin Nutr 78, 480-484.

63. Singer MR, Moore LL, Garrahie EJ, et al. (1995) The tracking of nutrient intake in young children: The Framingham Children's Study. Am J Public Health 85, 1673-1677.

64. Boulton TJ, Magarey AM \& Cockington RA (1995) Tracking of serum lipids and dietary energy, fat, and calcium intake 1 to 15 years. Acta Paediatr 84, 1050-1055.

65. Petit M (2002) A randomised school-based jumping intervention confers site and maturity-specific benefits on bone structural properties in girls: a hip structural analysis study. J Bone Miner Res 17, 363-372.

66. Willett WC, Howe GR \& Kushi LH (1997) Adjustment for total energy intake in epidemiologic studies. Am J Clin Nutr 65, 1220S-1231S.

67. Chan GM, Hoffman K \& McMurry M (1995) Effects of dairy products on bone and body composition in pubertal girls. J Pediatr 126, 551-556.

68. Cadogan J, Eastell R, Jones N, et al. (1997) Milk intake and bone mineral acquisition in adolescent girls: randomised, controlled intervention trial. BMJ 315, 1255-1260.

69. Merrilees MJ, Smart EJ, Gilchrist NL, et al. (2000) Effects of dairy food supplements on bone mineral density in teenage girls. Eur J Nutr 39, 256-262.

70. Volek JS, Gómez AL, Scheett TP, et al. (2003) Increasing fluid milk favorably affects bone mineral density responses to resistance training in adolescent boys. J Am Diet Assoc 103, 1353-1356.

71. Cheng S, Lyytikäinen A, Kröger A, et al. (2005) Effects of calcium, dairy product, and vitamin D supplementation on bone mass accrual and body composition in 10-12-y-old girls: a 2-y randomized trial. Am J Clin Nutr 82, 1115-1126.

72. Lau EMC, Lynn H, Chan YH, et al. (2004) Benefits of milk powder supplementation on bone accretion in Chinese children. Osteoporos Int 15, 654-658.

73. Weber D, Stark L, Ittenbach R, et al. (2017) Building better bones in childhood: a randomized controlled study to test the efficacy of a dietary intervention program to increase calcium intake. Eur J Clin Nutr 71, 788-794.

74. Vogel K, Martin B, McCabe L, et al. (2017) The effect of dairy intake on bone mass and body composition in early pubertal girls and boys: a randomized controlled trial. Am J Clin Nutr 105, 1214-1229.

75. Du X, Zhu K, Trube A, et al. (2004) School-milk intervention trial enhances growth and bone mineral accretion in Chinese girls aged 10-12 years in Beijing. $\mathrm{Br}$ J Nutr 92, 159-168.

76. Lappe J, Rafferty K, Davies K, et al. (2004) Girls on a highcalcium diet gain weight at the same rate as girls on a normal diet: a pilot study. J Am Diet Assoc 104, 1361-1367.

77. Li P, Fan C, Lu Y, et al. (2016) Effects of calcium supplementation on body weight: a meta-analysis. Am J Clin Nutr 104, 1263-1273.

78. Arnberg K, Mølgaard C, Michaelsen KF, et al. (2012) Skim milk, whey, and casein increase body weight and whey and casein increase the plasma C-peptide concentration in overweight adolescents. J Nutr 142, 2083-2090.

79. Larnkjaer A, Arnberg K, Michaelsen KF, et al. (2015) Effect of increased intake of skimmed milk, casein, whey or water on body composition and leptin in overweight adolescents: a randomized trial. Pediatr Obes 10, 461-467.

80. Albala C, Ebbeling C, Cifuentes M, et al. (2008) Effects of replacing the habitual consumption of sugar-sweetened beverages with milk in Chilean children. Am J Clin Nutr 88, 605-611.

81. Lappe J, McMahon D, Laughlin A, et al. (2017) The effect of increasing dairy calcium intake of adolescent girls on changes in body fat and weight. Am J Clin Nutr 105, 1046-1053.

82. St-Onge MP, Goree LL \& Gower B (2009) High-milk supplementation with healthy diet counseling does not affect weight loss but ameliorates insulin action compared with low-milk supplementation in overweight children. J Nutr 139, 933-938.

83. Kelishadi R, Zemel M, Hashemipour M, et al. (2009) Can a dairy-rich diet be effective in long-term weight control of young children? J Am Coll Nutr 28, 601-610. 
84. Chen M, Pan A, Malik VS, et al. (2012) Effects of dairy intake on body weight and fat: a meta-analysis of randomized controlled trials. Am J Clin Nutr 96, 735-747.

85. Abargouei A, Janghorbani M, Salehi-Marzijarani M, et al. (2012) Effect of dairy consumption on weight and body composition in adults: a systematic review and meta-analysis of randomized controlled clinical trials. Int J Obes 36, 1485-1493.

86. Ghayour-Mobarhan M, Sahebkar A, Vakili R, et al. (2009) Investigation of the effect of high dairy diet on body mass index and body fat in overweight and obese children. Indian J Pediatr 76, 1145-1150.

87. Du X, Greenfield H, Fraser DR, et al. (2001) Vitamin D deficiency and associated factors in adolescent girls in Beijing. Am J Clin Nutr 74, 494-500.

88. Fellows P \& Hampton A (editors) (1992) Chapter 9: Milk and milk products. In Small-scale Food Processing: A Guide for Appropriate Equipment. London: Intermediate Technology Publications. http://www.fao.org/Wairdocs/X5434E/ x5434e0d.htm (accessed June 2018).

89. Kang SH, Kim JU, Imm JY, et al. (2006) The effects of dairy processes and storage on insulin-like growth factor-I (IGFI) content in milk and in model IGF-1-fortified dairy products. J Dairy Sci 89, 402-409.

90. Weaver C, Campbell W, Teegarden D, et al. (2011) Calcium, dairy products, and energy balance in overweight adolescents: a controlled trial. Am J Clin Nutr 94, 1163-1170.

91. Maffeis C, Pietrobelli A, Grezzani A, et al. (2001) Waist circumference and cardiovascular risk factors in prepubertal children. Obes Res 9, 179-187.

92. Savva SC, Tornaritis M, Savva ME, et al. (2000) Waist circumference and waist-to-height ratio are better predictors of cardiovascular disease risk factors in children than body mass index. Int J Obes Relat Metab Disord 24, 14531458.

93. Dougkas A, Reynolds C, Givens I, et al. (2011) Associations between dairy consumption and body weight: a review of the evidence and underlying mechanisms. Nutr Res Rev 24, $72-95$.

94. Major G, Chaput J, Ledoux M, et al. (2008) Recent developments in calcium-related obesity research. Obes Rev 9, 428-445.

95. Soares M, Murhadi L, Kurpad A, et al. (2012) Mechanistic roles for calcium and vitamin $\mathrm{D}$ in the regulation of body weight. Obes Rev 13, 592-605.

96. Zemel M (2002) Regulation of adiposity and obesity risk by dietary calcium: mechanisms and implications. J Am Coll Nutr 21, 146S-151S.

97. Shi H, Norman AW, Okamura WH, et al. (2001) 1 1 ,25Dihydroxyvitamin $\mathrm{D}_{3}$ modulates human adipocyte metabolism via nongenomic action. FASEB J 15, 2751-2753.

98. Zemel M (2003) Role of dietary calcium and dairy products in modulating adiposity. Lipids 38, 139-146.

99. Xue B, Greenberg AG, Kraemer FB, et al. (2001) Mechanism of intracellular calcium $\left(\left[\mathrm{Ca}^{2+}\right]_{\mathfrak{i}}\right)$ inhibition of lipolysis in human adipocytes. FASEB J 15, 2527-2529.

100. Gonzalez JT, Rumbold PL \& Stevenson EJ (2012) Effect of calcium intake on fat oxidation in adults: a meta-analysis of randomized, controlled trials. Obes Rev 13, 848-857.

101. Bortolotti M, Rudelle S, Schneiter P, et al. (2008) Dairy calcium supplementation in overweight or obese persons: its effect on markers of fat metabolism. Am J Clin Nutr 88, 877885 .

102. Dugan C, Barona J \& Fernandez M (2014) Increased dairy consumption differentially improves metabolic syndrome markers in male and female adults. Metab Syndr Relat Disord 12, 62-69.
103. Sun X \& Zemel MB (2007) Calcium and 1,25-dihydroxyvitamin $\mathrm{D}_{3}$ regulation of adipokine expression. Obesity (Silver Spring) 15, 340-348.

104. Zemel M (2005) The role of dairy foods in weight management. J Am Coll Nutr 24, 537S-546S.

105. Pihlanto-Leppala A, Koskinen P, Piilola K, et al. (2000) Angiotensin I-converting enzyme inhibitory properties of whey protein digests: concentration and characterization of active peptides. J Dairy Res 67, 53-64.

106. Shah N (2000) Effects of milk-derived bioactives: an overview. Br J Nutr 84, Suppl. 1, S3-S10.

107. Belury M (2002) Dietary conjugated linoleic acid in health: physiological effects and mechanisms of action. Annu Rev Nutr 22, 505-531.

108. Ing S \& Belury MA (2011) Impact of conjugated linoleic acid on bone physiology: proposed mechanism involving inhibition of adipogenesis. Nutr Rev 69, 123-131.

109. Marten B, Pfeuffer M \& Schrezenmeir J (2006) Mediumchain triglycerides. Int Dairy J 16, 1374-1382.

110. Moon HS, Lee HG, Seo JH, et al. (2009) Antiobesity effect of PEGylated conjugated linoleic acid on high-fat diet-induced obese C57BL/6J (ob/ob) mice: attenuation of insulin resistance and enhancement of antioxidant defenses. J Nutr Biochem 20, 187-194.

111. Denke MA, Fox MM \& Schulte MC (1993) Short-term dietary calcium fortification increases fecal saturated fat content and reduces serum lipids in men. J Nutr 123, 10471053.

112. Jacobsen R, Lorenzen JK, Toubro S, et al. (2005) Effect of short-term high dietary calcium intake on 24-h energy expenditure, fat oxidation, and fecal fat excretion. Int $J$ Obes 29, 292-301.

113. Jandacek R (1991) The solubilization of calcium soaps by fatty acids. Lipids 26, 250-253.

114. Christensen R, Lorenzen JK, Svith CR, et al. (2009) Effect of calcium from dairy and dietary supplements on faecal fat excretion: a meta-analysis of randomized controlled trials. Obes Rev 10, 475-486.

115. Lutwak L, Laster L, Gitelman H, et al. (1964) Effects of high dietary calcium and phosphorus on calcium, phosphorus, nitrogen and fat metabolism in children. Am J Clin Nutr 14, $76-82$.

116. Goran M \& Gower B (1999) Relation between visceral fat and disease risk in children and adolescents. Am J Clin Nutr 70, 149S-156S.

117. Huang TT \& McCrory MA (2005) Dairy intake, obesity, and metabolic health in children and adolescents: knowledge and gaps. Nutr Rev 63, 71-80.

118. Tordoff MG (2001) Calcium: taste, intake, and appetite. Physiol Rev 81, 1567-1597.

119. Tordoff MG (2008) Gene discovery and the genetic basis of calcium consumption. Physiol Behav 94, 649-659.

120. Wennersberg MH, Smedman A, Turpeinen AM, et al. (2009) Dairy products and metabolic effects in overweight men and women: results from a 6-mo intervention study. $A m J$ Clin Nutr 90, 960-968.

121. Gonzalez J \& Stevenson E (2013) Calcium co-ingestion augments postprandial glucose-dependent insulinotropic peptide1-42, glucagon-like peptide-1 and insulin concentrations in humans. Eur J Nutr 53, 375-385.

122. Gonzalez J, Green B, Campbell M, et al. (2014) The influence of calcium supplementation on substrate metabolism during exercise in humans: a randomized controlled trial. Eur J Clin Nutr 68, 712-718.

123. Gonzalez J, Green B, Brown M, et al. (2015) Calcium ingestion suppresses appetite and produces acute 
overcompensation of energy intake independent of protein in healthy adults. J Nutr 145, 476-482.

124. Bendtsen L, Lorenzen J, Bendsen N, et al. (2013) Effect of dairy proteins on appetite, energy expenditure, body weight, and composition: a review of the evidence from controlled clinical trials. Adv Nutr 4, 418-438.

125. Shafer RB, Levine AS, Marlette JM, et al. (1985) Do calories, osmolality, or calcium determine gastric emptying? Am J Physiol 248, R479-R483.

126. Jordi J, Herzog B, Camargo SM, et al. (2013) Specific amino acids inhibit food intake via the area postrema or vagal afferents. J Physiol 591, 5611-5621.

127. Nakajima S, Hira T \& Hara H (2012) Calcium-sensing receptor mediates dietary peptide-induced CCK secretion in enteroendocrine STC-1 cells. Mol Nutr Food Res 56, 753-760.

128. Mace O, Schindler M \& Patel S (2012) The regulation of Kand L-cell activity by GLUT2 and the calcium-sensing receptor CasR in rat small intestine. J Physiol 590, 2917-2936.

129. Behar J, Hitchings M \& Smyth RD (1977) Calcium stimulation of gastrin and gastric acid secretion: effect of small doses of calcium carbonate. Gut 18, 442-448.

130. Villarroel P, Villalobos E, Reyes M, et al. (2014) Calcium, obesity, and the role of the calcium-sensing receptor. Nutr Rev 72, 627-637.

131. Marette A \& Picard-Deland E (2014) Yogurt consumption and impact on health: focus on children and cardiometabolic risk. Am J Clin Nutr 99, 1243S-1247S.

132. Moreno L, Bel-Serrat S, Santaliestra-Pasías A, et al. (2015) Dairy products, yogurt consumption, and cardiometabolic risk in children and adolescents. Nutr Rev 73, 8-14.

133. Karlsson CL, Onnerfalt J, Xu J, et al. (2012) The microbiota of the gut in preschool children with normal and excessive body weight. Obesity 20, 2257-2261.

134. Bervoets L, Van Hoorenbeeck K, Kortleven I, et al. (2013) Differences in gut microbiota composition between obese and lean children: a cross-sectional study. Gut Pathog 5, 10.

135. Kalliomaki M, Collado MC, Salminen S, et al. (2008) Early differences in fecal microbiota composition in children may predict overweight. Am J Clin Nutr 87, 534-538.

136. Arora T, Singh S \& Sharma RK (2013) Probiotics: interaction with gut microbiome and antiobesity potential. Nutrition 29, 591-596.

137. Luoto R, Kalliomäki M, Laitinen K, et al. (2010) The impact of perinatal probiotic intervention on the development of overweight and obesity: follow-up study from birth to 10 years. Int J Obes 34, 1531-1537.

138. Safavi M, Farajian S, Kelishadi R, et al. (2013) The effects of synbiotic supplementation on some cardio-metabolic risk factors in overweight and obese children: a randomized triple-masked controlled trial. Int J Food Sci Nutr 64, 687-693.

139. Günther AL, Remer T, Kroke A, et al. (2007) Early protein intake and later obesity risk: which protein sources at which time points throughout infancy and childhood are important for body mass index and body fat percentage at 7 y of age? Am J Clin Nutr 86, 1765-1772.

140. Braun K, Erler N, Kiefte-de Jong J, et al. (2016) Dietary intake of protein in early childhood is associated with growth trajectories between 1 and 9 years of age. $J$ Nutr 146, 2361-2367.

141. Hoppe C, Molgaard C, Juul A, et al. (2004) High intakes of skimmed milk, but not meat, increase serum IGF-I and IGFBP-3 in eight-year-old boys. Eur J Clin Nutr 58, 12111216.
142. Hoppe C, Udam TR, Lauritzen L, et al. (2004) Animal protein intake, serum insulin-like growth factor I, and growth in healthy 2.5-y-old Danish children. Am J Clin Nutr 80, $447-452$.

143. Rogers I, Emmett P, Gunnell D, et al. (2006) Milk as a food for growth? The insulin-like growth factors link. Public Health Nutr 9, 359-368.

144. Koletzko B (2006) Long-term consequences of early feeding on later obesity risk. Nestle Nutr Workshop Ser Pediatr Program 58, 1-18.

145. Rolland-Cachera MF, Deheeger M, Akrout M, et al. (1995) Influence of macronutrients on adiposity development: a follow up study of nutrition and growth from 10 months to 8 years of age. Int J Obes Relat Metab Disord 19, 573578.

146. Fall CH, Clark PM, Hindmarsh PC, et al. (2000) Urinary GH and IGF-I excretion in nine year-old children:relation to sex, current size and size at birth. Clin Endocrinol (Oxf) 53, 69-76.

147. Garnett S, Cowell CT, Bradford D, et al. (1999) Effects of gender, body composition and birth size on IGF-I in 7- and 8-year-old children. Horm Res 52, 221-229

148. Juul A, Holm K, Kastrup KW, et al. (1997) Free insulin-like growth factor I serum levels in 1430 healthy children and adults, and its diagnostic value in patients suspected of growth hormone deficiency. J Clin Endocrinol Metab 82, 2497-2502

149. Pal S \& Ellis V (2010) The acute effects of four protein meals on insulin, glucose, appetite and energy intake in lean men. Br J Nutr 104, 1241-1248.

150. Akhavan T, Luhovyy BL, Brown PH, et al. (2010) Effect of premeal consumption of whey protein and its hydrolysate on food intake and postmeal glycemia and insulin responses in young adults. Am J Clin Nutr 91, 966-975.

151. Bjørnshave A \& Hermansen K (2014) Effects of dairy protein and fat on the metabolic syndrome and type 2 diabetes. Rev Diabet Stud 11, 153-166.

152. Hill DJ \& Milner RD (1985) Insulin as a growth factor. Pediatr Res 19, 879-886.

153. Dove ER, Hodgson JM, Puddey IB, et al. (2009) Skimmed milk compared with a fruit drink acutely reduces appetite and energy intake in overweight men and women. $A m J$ Clin Nutr 90, 70-75.

154. Dougkas A, Minihane AM, Givens DI, et al. (2011) Differential effects of dairy snacks on appetite ratings, but not overall energy intake. Proc Nutr Soc 70, E131.

155. Maersk M, Belza A, Holst JJ, et al. (2012) Satiety scores and satiety hormone response after sucrose-sweetened soft drink compared with isocaloric semi-skimmed milk and with non-caloric soft drink: a controlled trial. Eur J Clin Nutr 66, 523-529.

156. Onvani S, Haghighatdoost F, Surkan PJ, et al. (2016) Dairy products, satiety and food intake: A meta-analysis of clinical trials. Clin Nutr 36, 389-398.

157. Brindal E, Baird D, Slater A, et al. (2012) The effect of beverages varying in glycaemic load on postprandial glucose responses, appetite and cognition in 10-12-yearold school children. Br J Nutr 110, 529-537.

158. Mehrabani S, Safavi SM, Asemi M, et al. (2015) Effects of low-fat milk consumption at breakfast on satiety and shortterm energy intake in 10- to 12-year-old obese boys. Eur J Nutr 55, 1389-1396.

159. Kling SMR, Roe LS, Sanchez CE, et al. (2016) Does milk matter: is children's intake affected by the type or amount of milk served at a meal? Appetite 105, 509-518. 
160. Vien S, Luhovyy BL, Patel BP, et al. (2017) Pre- and within meal effects of fluid dairy products on appetite, food intake, glycemia and regulatory hormones in children. $A p p l$ Physiol Nutr Metab 42, 302-310.

161. Green BP, Stevenson EJ \& Rumbold PLS (2017) Metabolic, endocrine and appetite-related responses to acute and daily milk snack consumption in healthy, adolescent males. Appetite 108, 93-103.

162. Andersen LBB, Arnberg K, Trolle E, et al. (2016) The effects of water and dairy drinks on dietary patterns in overweight adolescents. Int J Food Sci Nutr 67, 314-324.

163. Hendrie GA \& Golley RK (2011) Changing from regular-fat to low-fat dairy foods reduces saturated fat intake but not energy intake in 4-13-y-old children. Am J Clin Nutr 93, 1117-1127.

164. Golley RK \& Hendrie GA (2012) The impact of replacing regular- with reduced-fat dairy foods on children's wider food intake: secondary analysis of a cluster RCT. Eur J Clin Nutr 66, 1130-1134.

165. Newby P, Peterson K, Berkey C, et al. (2004) Beverage consumption is not associated with changes in weight and body mass index among low-income preschool children in North Dakota. J Am Diet Assoc 104, 1086-1094.

166. Faith MS, Dennison BA, Edmunds LS, et al. (2006) Fruit juice intake predicts increased Adiposity gain in children from low-income families: weight status-by-environment interaction. Pediatrics 6, 2066-2075.

167. Tam CS, Garnett SP, Cowell CT, et al. (2006) Soft drink consumption and excess weight gain in Australian school students: results from the Nepean study. Int J Obes $\mathbf{3 0}$, 1091-1093.

168. Johnson L, Mander AP, Jones LR, et al. (2007) Is sugar-sweetened beverage consumption associated with increased fatness in children? Nutrition 23, 557563.

169. Kral TVE, Stunkard AJ, Berkowitz RI, et al. (2008) Beverage consumption patterns of children born at different risk of obesity. Obesity (Silver Spring) 16, 1802-1808.

170. Fiorito LM, Marini M, Francis LA, et al. (2009) Beverage intake of girls at age $5 \mathrm{y}$ predicts adiposity and weight status in childhood and adolescence. Am J Clin Nutr 90, 935-942.

171. Huus K, Brekke HK \& Ludvigsson JF (2009) Relationship of food frequencies as reported by parents to overweight and obesity at 5 years. Acta Paediatr 98, 139-143.

172. Lin SL, Tarrant M, Hui LL, et al. (2012) The role of dairy products and milk in adolescent obesity: Evidence from Hong Kong's "Children of 1997" birth cohort. PLOS ONE 7, e 52575 .

173. Gibbons M, Gilchrist N, Frampton C, et al. (2004) The effects of a high calcium dairy food on bone health in prepubertal children in New Zealand. Asia Pac J Clin Nutr 13, 341-347.

174. DeJongh ED, Binkley TL \& Specker BL (2006) Fat mass gain is lower in calcium-supplemented than in unsupplemented preschool children with low dietary calcium intakes. $A m J$ Clin Nutr 84, 1123-1127. 